Provided for non-commercial research and education use. Not for reproduction, distribution or commercial use.

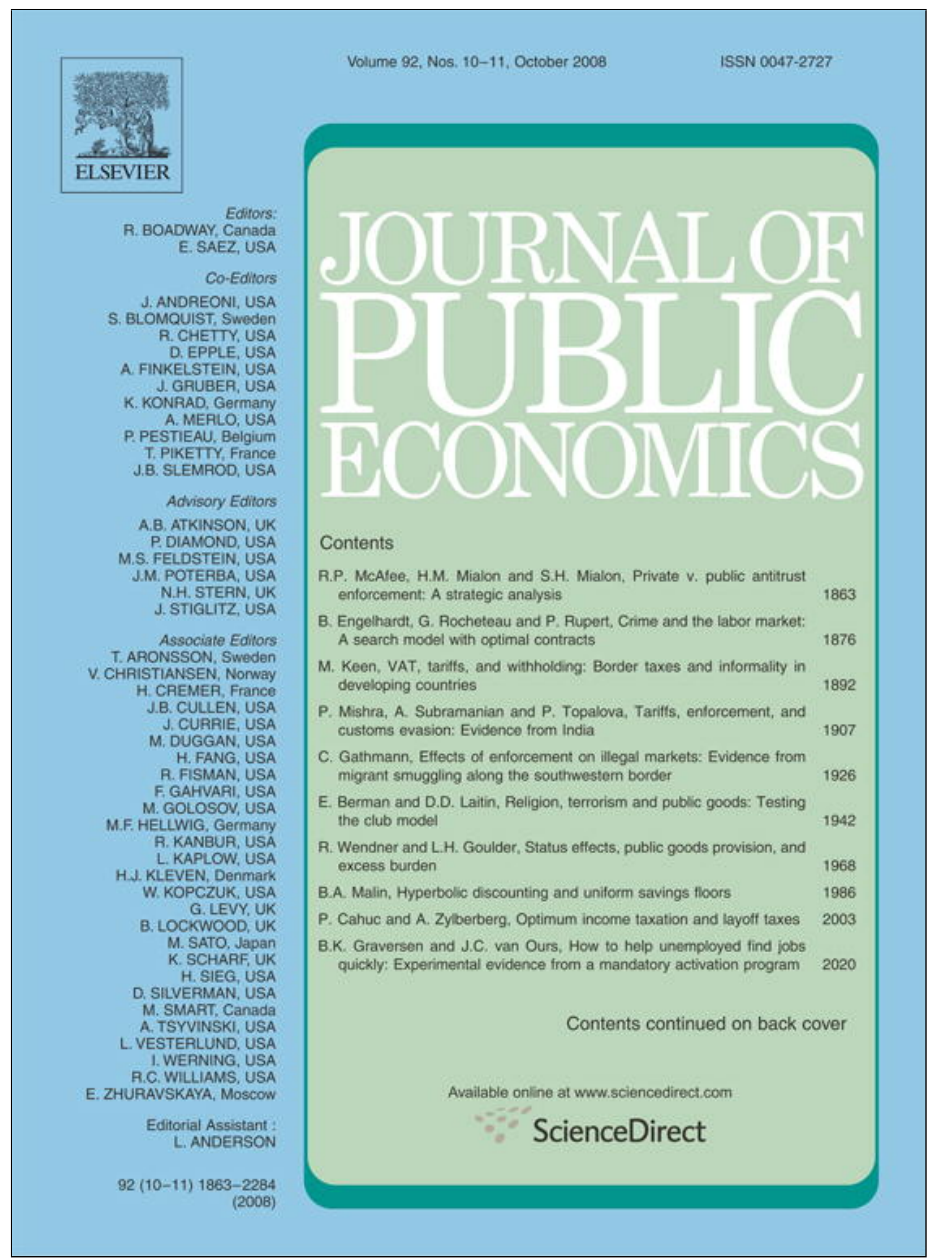

This article appeared in a journal published by Elsevier. The attached copy is furnished to the author for internal non-commercial research and education use, including for instruction at the authors institution and sharing with colleagues.

Other uses, including reproduction and distribution, or selling or licensing copies, or posting to personal, institutional or third party websites are prohibited.

In most cases authors are permitted to post their version of the article (e.g. in Word or Tex form) to their personal website or institutional repository. Authors requiring further information regarding Elsevier's archiving and manuscript policies are encouraged to visit:

http://www.elsevier.com/copyright 


\title{
Religion, terrorism and public goods: Testing the club model ${ }^{\natural}$
}

\author{
Eli Berman ${ }^{\mathrm{a}, \mathrm{b}, *}$, David D. Laitin ${ }^{\mathrm{c}}$ \\ a Department of Economics, UC San Diego, United States \\ ${ }^{\mathrm{b}}$ National Bureau of Economic Research, United States \\ c Department of Political Science, CISAC Stanford University, Encina H all C423, Stanford, CA 94305, United States
}

\section{A R T I C L E I N F O}

\section{Article history:}

Received 3 January 2007

Received in revised form 17 March 2008

Accepted 18 March 2008

Available online 26 March 2008

\section{JEL classification:}

H41

H56

Z12

D2

J0

017

\section{Keywords:}

Terrorism

Economics of religion

Club goods

Public goods

Insurgency

Sects

Middle East

Suicide attacks

Development economics

\begin{abstract}
A B S T R A C T
Can rational models, once theological explanations are discredited, explain why certain radical religious rebels are so successful in perpetrating suicide attacks? The fundamental barrier to success turns out not to be recruiting suicide attackers; there is a rational basis for volunteering. Rather, the barrier is the danger of other operatives defecting. A club model, portraying voluntary religious organizations as efficient providers of local public goods, explains how they weed out potential defectors by requiring sacrifices as signals of commitment. They are thereby able to succeed in risky terrorist attacks. The model has testable implications for tactic choice and damage achieved by clubs and other rebel organizations. Data spanning a half-century on both terrorists and civil war insurgents, much from Middle East sources and Israel/Palestine, reveal that: a) missions organized by radical religious clubs that provide benign local public goods are both more lethal and are more likely to be suicide attacks than missions organized by other terrorist groups with similar aims and theologies; and b) suicide attacks are chosen when targets are "hard," i.e., difficult to destroy. Our results suggest benign tactics to counter radical religious terrorism and insurgency.
\end{abstract}

(c) 2008 Elsevier B.V. All rights reserved.

"We must examine the costs and benefits of continued armed operations."

M. Al Zahar, a Hamas leader, quoted in Al Quds, (East Jerusalem: October 1995). ${ }^{1}$

\footnotetext{
is We appreciate the comments of Mahmoud Al-Gamal, James Fearon, Andrea Hill, Laurence lannaccone, Peter Katzenstein, Alan Krueger, Timur Kuran, Howard Rosenthal, Bradley Ruffle, and Berman's colleagues at Boston University, Rice University and the University of California San Diego, as well as comments of participants in numerous conferences and seminars. Eva Meyersson Milgrom organized the Stanford suicide terrorism project. Her foresight spawned our collaboration. We thank Barak Bouks, Liang Choon Wang and Lindsay Heger for research assistance. Mistakes are our own. This project is supported by National Science Foundation grant \#0 214701 through the National Bureau of Economic Research, and by a Department of Homeland Security grant through the CREATE center at USC.

* Corresponding author. Economics 0508, UCSD, 9500 Gilman Dr., La Jolla CA 92 093, United States. Tel.: +1 858534 2858; fax: +1 8585347040.

E-mail addresses: elib@ucsd.edu (E. Berman), dlaitin@stanford.edu (D.D. Laitin).

${ }^{1}$ Mishal and Sela (2000), p. 71.
} 


\section{Introduction}

Why are religious radicals such lethal terrorists? Why would anyone choose suicide terrorism, which is very rare in civil wars? And why do suicide attackers generally target members of other religions? These questions seem to pose a challenge to modeling that assumes rational choice, suggesting instead an irrational group of psychopaths motivated by hatred and religious zealotry.

Yet members of these radical religious groups are hardly typical "bad guys." They exhibit productive, constructive and noble behaviors: acts of piety, charity and self-sacrifice. Their organizations are often efficient providers of valuable local public goods. Hamas, Hezbollah and Muqtada al Sadr's Mahdi Army all provide social services. The Taliban restored law and order to Afghanistan, halting poppy cultivation (for opium) and reducing crime. By securing trade routes they restored commerce (both legal and illegal) in Afghanistan. Hamas is a theological descendant of the Egyptian Muslim Brotherhood, which at its peak actively provided social services through charitable institutions. The Palestinian Muslim Brotherhood efficiently provides health care, schooling, welfare, disaster relief, and community services to needy communities in Gaza and the West Bank.

Psychological research indicates that suicide attackers are neither mentally disturbed nor motivated primarily by theology. ${ }^{2}$ Psychiatrist Ariel Merari interviewed failed suicide terrorists and the families of suicide terrorists. He found that all the attackers were psychologically healthy, and that none mentioned religiosity or promises of rewards in the afterlife as their main motivating force. The Tamil Tigers, who carried out the most suicide attacks in the 1980s, are nominally atheists.

Yet when they choose violence, religious radicals are devastatingly effective. The Taliban, who were not experienced fighters, managed to conquer and hold most of Afghanistan, an accomplishment unmatched by the Soviet military and not attempted by Western forces today. Hamas quickly evolved into the deadliest terrorist organization in Palestine, in the number of attacks conducted, the proportion of attacks that destroyed their targets, and the number of casualties per attack. By these measures it is much more effective than its secular rival, the Fatah's Tanzim, or than the (initially) more experienced Islamic Jihad. Hezbollah quickly became the dominant militant organization in southern Lebanon, expelling its secular Shia rival, Amal, and eventually forcing the withdrawal of Israeli forces.

Why suicide attacks? The suicide attack is a gruesome tactic of rebellion that necessitates losing a loyal cadre. Why would leaders of rebellions employ it? Under what conditions will suicide attacks succeed? What kinds of rebels use it most effectively?

This paper attempts to resolve those puzzles, the effectiveness of religious radicals at violence and their choice of suicide attacks, using an approach that assumes rational choice by individuals. Our argument draws on three literatures: the economic theory of clubs, the sociology of religion and the political science of insurgencies. We claim that radical religious terrorists and rebels are best understood not as theologically-motivated (most religious radicals are nonviolent) or as psychopaths, but as public good providers. We argue that their operational secret is an organizational form that deters defection, allowing them to penetrate high-value targets.

We take a unified analytic approach to extreme religious groups, applying the same club model to radical Islamists that has been used to explain the behavior of Christian and Jewish sects (Iannaccone, 1992; Berman, 2000). That club model is extended here to explain not only the benign activities of religious sects, but also their effectiveness at violence. Rationalizing behavior is not merely an analytical tool, but has a practical implications (Sprinzak, 2000). If we cannot explain destructive behaviors in a model in which individuals respond to incentives, what policy solutions could we recommend that are not themselves inherently destructive?

Before proceeding, some definitions will be useful. A religious radical is an individual who belongs to a group that distances itself from the mainstream culture by creating some sort of tension, as do Amish, or Hassidim. The words radical and sect will be interchangeable in that sense. ${ }^{3}$ In this usage a radical religious group need not be politically active or violent. Indeed, most radical religious Muslims, Christians and Jews are nonviolent and apolitical. We will also distinguish between two types of violent tactics chosen by rebels: insurgency and suicide attacks, as explained below.

Why belong to a sect? Imagine a community for which neither government nor markets function well. Local public goods usually provided by government such as public safety, law and order, and welfare services are poorly provided or absent; neither public nor private sectors efficiently deliver education, health services or insurance. It would be efficient for individuals in such a place to band together into communities that provide public safety, education, welfare services, and other local public goods through mutual aid. Iannaccone (1992) pointed out that religion is a natural organizing node for community provision of local public goods. Moreover the most puzzling features of religious sects, their propensity to limit choices (prohibitions) and to destroy resources and options (sacrifices), can be explained as internal incentive policies that allow clubs to efficiently provide services to members. Since members engage in joint production of local public goods during their hours of nonmarket time, market work is a distraction with a negative externality for other members. So efficient clubs should tax market wages. Lacking tax authority they turn to prohibitions on consumption as a crude but feasible method of lowering wages. Sacrifices can be explained as a costly signal of "commitment" to the community, or (less prosaically) as a signal of relatively poor economic options outside the club. A sacrifice serves as an initiation rite, securing membership - and with it access to club goods.

Iannaccone provides supporting evidence for the club model from data on Christian denominations, showing that more extreme prohibitions and sacrifices predict greater provision of public goods to members. Berman (2000) extends the club approach to ultra-orthodox Jews, showing that subsidies to sects dramatically increase prohibitions and sacrifices. The resulting

\footnotetext{
${ }^{2}$ See Merari (2004) and Kruglanski (2002). Hassan (2001) first pointed out that suicide attackers do not fit the usual profile of suicidal youth and are not otherwise psychotic. Berman and Laitin (2007) discuss the literature on the psychology of suicide attackers.

3 See Stark and Finke (2000) for a recent review of the concept of religious sects in the literature.
} 
reduction in the effective wages of ultra-orthodox Jewish women in Israel caused fertility to increase by over a child per woman. Duration of Yeshiva (full time religious seminary) attendance increased by over 10 years, all within two decades. Berman and Stepanyan (2005) extend the literature to Muslims, documenting high fertility and generally low returns to schooling among Muslim sects in five countries.

This paper applies that club approach to the puzzles of rebel effectiveness and suicide attacks. First, we argue that religious clubs are well suited to coordinated violence. Insurgency and terrorism are crucially sensitive to defection, so a club that extracts sacrifices as signals of commitment has an advantage. ${ }^{4}$ Second, we invoke the literature on insurgencies to explain clubs choosing suicide attacks. Where states are strong enough to protect targets well, rebel organizations cannot successfully use standard insurgency tactics. Yet under those conditions, suicide attacks remain effective. While recruiting suicide attackers is easier than many surmise, recruiting operatives resistant to defection in these high-stakes attacks is a first-order tactical problem. Radical religious clubs are better able to insulate themselves against defection.

In Section 2 we provide background, describing violent behavior and public good provision by Hamas, Hezbollah, and Taliban. We also use a newly-constructed dataset to describe two patterns in suicide terrorism. First, the environmental conditions favoring insurgency (Fearon and Laitin, 2003, henceforth FL), poor countries with rough terrain, do not predict the use of suicide attacks. Second, while insurgents tend to attack coreligionists, suicide attacks tend to target members of other religions. Our approach is also informed by a third finding from FL on factors that do not predict insurgency or suicide attacks: grievances, religious differences, and ethnic differences. That last finding motivates an organizational rather than theological approach to studying radical religious rebels.

In Section 3, we present a more formal version of the club model, extending lannaccone's public good-providing sect to include violent activity and the possibility of defection. We also formalize the concept of "hard targets" to explain when rebels choose suicide attacks. As targets are hardened (i.e., chances of successful destruction and escape are reduced) suicide attacks are increasingly chosen because they allow well-defended targets to be destroyed without apprehension. This is a critical concern for rebels in asymmetric conflicts since a strong state can use information from captured attackers to expose the network and arrest or kill its members. For hard enough targets this advantage outweighs the cost of losing a cadre (the attacker) with certainty. Thus as states become richer and better able to defend targets, suicide attacks are used more often - the first pattern described in the previous paragraph. Coreligionists tend to look similar. Thus attackers of the same religion as targets are hard to distinguish by profiling, making coreligionist victims soft targets because they are harder to defend; consequently - now for the second pattern attackers can kill coreligionists without resorting to suicide attacks.

We also ask why religious radicals so often choose suicide attacks. Rather than the conventional explanation, which is based on theological motivation, our approach emphasizes the tactical difficulty of operating against hard targets. We model the choice of tactics by rebels when targets can be either hard or soft and rebels are concerned about capture and defection. We first outline the beliefs that suicide attackers would need to hold for their actions to be deemed rational (Hamermesh and Soss, 1974; Elster, 2006; Becker and Posner, 2005; Wintrobe 2006). We then consider the attacker and his organization in a rational choice framework. The model, extending Iannaccone (1992) and Berman (2000, 2003), explains why "clubs" (which provide benign local public goods such as education and welfare) of a certain type are able to complete high-stakes suicide attacks despite strong incentives for operatives to defect.

In Section 4 we test implications of that model using data on terrorism from Israel, Palestine and Lebanon. We find that clubs are in fact more lethal than other terrorists, regardless of the type of attack. We also find that, as the Hard Targets argument predicts, suicide attacks are chosen against better defended targets. Combining the logic of clubs with that of suicide attacks, we find that radical religious clubs do in fact carry out suicide attacks more often and more effectively than do secular terrorists. Thus, our evidence suggests that theological motivations are overrated. Among three radical religious organizations with very similar theologies about Jihadist conflict, those with active local public good provision (Hamas and Hezbollah) are more lethal suicide terrorists than that without (the Palestinian Islamic Jihad). We also discuss how this approach might extend to Iraq, Sri Lanka and Chechnya.

Section 5 discusses implications for protecting hard targets from radical religious clubs. The better states and markets are at providing social services, the harder it is for insurgencies to organize around a social-service provision base and conduct highstakes attacks without fear of defection. These implications differ from those of conventional development economics (and political science) in critical ways. Another general conclusion for counter-terrorism is that the threat of defection is a powerful force limiting the tactical choices of terrorists. For instance, the assassination of Al-Qaeda leader Abu Musab Al-Zarqawi in June 2006, was based on information from a captured Al-Qaeda source transmitted to U.S. interrogators. In the Southern Philippines Abu Sayyaf terrorists have been killed or captured using intelligence obtained in return for generous rewards. In conclusion we suggest future empirical extensions.

\section{Background}

The Taliban, Hamas, Hezbollah and Muqtada al Sadr's Mahdi Army are examples of highly ritualistic, extremely conservative Muslim groups. They belong to a family of radical sects whose religious behavior represents a clear break from traditional practice. They augment the prohibitions of mainstream Islamic practice, such as dress codes and shaving. They tend to segregate themselves from other Muslims and to be intolerant of deviation, in contrast to Islam's historical tolerance. Though often termed

\footnotetext{
4 The analysis evokes Becker's theory of rational crime (Becker, 1968), in that individuals weigh the benefits of remaining loyal to, or defecting from, behavioral norms. Yet here the stakes are higher, as the norms are those of an illegal rebel organization that is endangered by the defection of even a single member.
} 
"fundamentalist" - as if returning to some historic norm of practice, these groups actually adhere to norms unprecedented in their extremism. The roots of current radical Islam date back only to the 1920s with the establishment by al-Banna of the Muslim Brotherhood (hereafter MB) in Egypt and Mawdudi's subsequent founding of the Jamaat-al-Islami in Pakistan. ${ }^{5}$

The core beliefs of radical Islamists clash with those of Western liberalism in their view of an individual's place within society. In the Western liberal approach individuals have rights and obligations in a direct relationship with the state. Public economics, for example, typically designs policy for states in relationship to individuals, not groups. In contrast, radical Islam derives from a more historically relevant approach: an individual's primary relationship is with a clan, sect or tribe, and through that with the sovereign (Black, 2001, p. 309). Clans, sects and tribes tend to be suspicious and jealous of competing affiliations.

The strong affiliations that individuals seek with clans, sects and tribes are easier to understand if we bear in mind that these groups thrive in places where government is a poor provider of local public goods such as health care, education and public safety and where the market is an inefficient provider of income and insurance. In that environment, group affiliation is a source of mutual insurance; providing protection, health care, income, food, clothing and the like. Though money need not change hands, that insurance relationship is nonetheless economic. ${ }^{6}$ Such relationships with a group much smaller than the state have been ubiquitous historically. They survive in the West in the form of radical religious sects like ultra-orthodox Jews and Christian Anabaptists (such as Hutterites and Mennonites) who provide extremely high levels of mutual aid to community members.

An efficient market economy and a functioning state are both threats to these affiliations; they reduce the need for the services that these groups provide and reduce the nonmarket hours available to members to provide services to others. Like radical Islam, radical Christian and Jewish sects often seek to distance members from market economies. Though the vast majority of sect activity is benign, we now turn our focus on the puzzling effectiveness of religious radicals at violence, beginning with the Taliban.

\subsection{Taliban}

Afghanistan is a famously ungovernable country, which has suffered 23 years of civil war at an appalling cost of one and a half million lives. ${ }^{7}$ The Mujaheddin, a loose tribe-based alliance of Islamic militants conducted a successful insurgency that eventually expelled a Soviet occupation. They had U.S. and Saudi aid, administered by Pakistani intelligence (ISI). Those subsidies were remarkably effective in expelling the Soviets, but radicalized Afghani society:

"Prior to the war the Islamicists barely had a base in Afghan society, but with money and arms from the CIA pipeline and support from Pakistan, they built one and wielded tremendous clout." (Rashid, 2000, p. 19).

By the mid 1990s, the Pashtun south had collapsed economically. It was run by former Mujaheddin warlords in fiefdoms ranging in size from a few provinces to single villages. During this particularly chaotic period, the Taliban emerged in Kandahar, the largest city in the south. Rashid (2000) emphasizes economic factors contributing to their formation. He describes a chaotic scene of warlords battling each other, looting businesses and infrastructure (including telephone poles), and kidnapping and raping children (Rashid, 2000, p. 21).

Banditry on the roads was an expensive obstacle for traders and smugglers. With alternate routes in northern Afghanistan blocked by heavy fighting, a route through Kandahar and Herat was the best chance for trade from Pakistan to Iran and Turkmenistan. By the fall of 1994 the Pakistani government backed an effort by the ISI (Pakistani Intelligence) and Pakistani truckers to open this route. When a trial convoy was held up by warlords near Kandahar, a small, largely unknown group of radical Islamists, the Taliban, conveniently emerged to free it, and to conquer Kandahar with minimal casualties. The second largest city in Afghanistan was taken by simply bribing the local warlords to surrender. The Taliban were well-armed with rifles, mortars, ammunition and vehicles acquired by raiding an ammunition dump on the Pakistani border. The Taliban were soon operating a safe single-toll road through the Kandahar region, a feat the warlords could not accomplish. By December they had recruited 12,000 students from the religious schools of the radical Islamic Juma'at al Islamiya (JUI) of Pakistan, mostly the sons of Afghan refugee families. Within three months the Taliban had efficiently conquered 12 of 31 provinces of Afghanistan, either by fighting, intimidating, or bribing local warlords to surrender (Rashid, 2000, p. 33). They collected arms, imposed law and order, and opened roads. ${ }^{8}$ The increase in commerce was significant, immediately lowering the price of food (Rashid, 2000, p. 35).

The Taliban proceeded to conquer and control some $90 \%$ of Afghanistan, a feat unmatched by the Soviet Union. With Taliban protection, smuggling prospered. (Pakistani customs revenue fell by $\$ 400 \mathrm{~m}$ between 1993 and 1997 (Rashid, p. 192)). The Taliban protected most of the \$1B Afghan-Pakistani drug trade, their control so complete that they could ban opium cultivation in 2000. The truly remarkable aspect of this period bears emphasis: A few hundred seminary students with relatively little military experience created a militia effective enough to conquer Afghanistan, a country in which Western forces have had trouble securing even the capital. Of all the allies that the ISI could have (and did) choose, why is it that the group with the most extreme religious

\footnotetext{
5 The Egyptian MB has evolved to be more a political-religious party than a sect (Mitchell, 1969), though tension with secular culture has always been an essential component.

${ }^{6}$ Ben-Porath (1980) emphasizes nonmarket exchange in his "F-connection" approach to sociology.

7 Rashid (2000), and Davis (1999) describe the Afghan civil war, the Mujaheddin, and the rise of the Taliban.

8 Davis (1999), relying on several sources, also emphasizes the role of Pakistani economic interests in the formation of the Taliban. The Taliban version of their movements' birth stresses not safe roads but public safety of another kind. They claim to have been a group of seminary students, led by Mullah Omar, a Mujahhedin veteran, who were enlisted by the local population to prevent the rape of teenage girls and boys on their way to school.
} 
practices was the most efficient at securing the safety of convoys and ordinary people, and at conquering and controlling Afghanistan?

\subsection{Hamas}

Just as the Taliban militia are an offshoot of the nonviolent JUI, Hamas is a descendant of the MB, the first modern radical religious movement in Islam. ${ }^{9}$ The MB was founded by Hasan al-Banna in Egypt in 1928 with the aims of reinvigorating Islam through individual piety and self-improvement, fighting the insidious force of assimilation into materialist Western culture, and establishing an Islamic state. Members met weekly in small groups, reinforcing a set of basic prohibitions on gambling, alcohol, adultery and usury. The MB established a broad network of mosques, boys and girls schools, youth groups, clinics, hospitals, charities, trade unions, night schools for workers, and even factories. These drew considerable public support both as social-service providers and as a focus of religious and political expression.

In 1948 a splinter terrorist organization of the MB, the "Secret Apparatus," carried out a campaign of bombing and political assassination, including among their victims the Egyptian Prime Minister. The government suppressed the MB. Al-Banna was shot in the street, allegedly by a government agent. Since then the MB has been illegal but tolerated in Egyptian society and politics, sometimes courted by government but often suppressed.

In the 1950s an imprisoned MB member, Sayyid Qutb, developed the theology of militant radical Islam. He preached that religious communities could only survive if segregated from insidious secular culture. Moreover, Qutb preached that violent revolt was a religious duty, both against the secular West and against the secular government of Egypt. His call to violence was rejected by most Muslims, including the Egyptian MB (Mitchell, 1969). Muslim theology is generally tolerant of other cultures, permitting warfare only in self-defense and rejecting violence in religious matters. ${ }^{10}$

Branches of the MB appeared in Gaza and the West Bank in the 1950s. In 1971 Sheikh Ahmed Yassin founded an MB affiliate Congress (Mujamah) in Gaza. Though Muslims in the West Bank and Gaza were relatively secular at the time, Sheikh Yassin soon gained popular support by establishing a social-service network of medical clinics, schools, charities, support for orphans, drug treatment centers, youth clubs, sports clubs and mosques (Mishal and Sela, 2000; Juergensmeyer, 2000, p. 78). The filled gaps in the social services provided by the Israeli occupational government, charities and international organizations, especially among refugees. Congress was financed by tithing (zakat) and by support from Arabs abroad. ${ }^{11}$

Yassin's Congress shared Al-Banna's agenda: personal ethical conduct, personal piety and the eventual establishment of a local Islamic government. In contrast to their secular rival, the Fatah, (the dominant party within the Palestinian Liberation Organization or PLO), the MB saw the liberation of Palestine as a long term goal to be deferred till ethical conduct and local Islamic government were established. The MB were nonviolent, except for some skirmishes with Fatah supporters. They contributed to an increase in religious practice in the 1980s in the West Bank and Gaza: dress codes were more stringently observed and outward signs of piety increased, including the frequency of prayer. This occurred especially in Gaza, which is poorer, and where the MB have more support and institutions.

Hamas was founded in 1988 as a result of the first Palestinian Intifada, a spontaneous revolt against Israeli occupation (Schiff and Ya'ari, 1990). Sheikh Yassin's local organizers urged him to endorse the revolt and establish a militia, lest the MB lose popular support to Fatah, which was harnessing the outburst of nationalism. Yassin eventually agreed, establishing a secret militant organization, Hamas, separating it to protect the social-service institutions from reprisal. Hamas called for violent opposition to Israeli occupation. It underwent an ideological shift, adopting a nationalist position more extreme than that of Fatah, making the immediate conquest of all Palestine (not just the West Bank and Gaza) a religious obligation. This expensive change in ideology predictably provoked a campaign of arrests and suppression by the Israeli army, putting members at high risk of arrest. That ideological shift would eventually also provoke reprisal by the Fatah-led government after the 1993 Oslo accords.

Hamas soon became a singularly effective rebel organization: hard to penetrate, disciplined, adequately funded, well trained and committed. Members regularly risked arrest and endangered their lives by confronting soldiers, assassinating collaborators, organizing and carrying out terrorist attacks. Hamas suicide bombings of buses in Israel in 1996 delivered a close Israeli election to the political right, hobbling the Oslo process which Hamas opposed.

\subsection{Hezbollah}

Hezbollah is another radical religious group that shocked Western forces with its capability. It seemed to emerge from nowhere in 1982 in South Lebanon. Hezbollah surprised Israeli forces, U.S. and French peacekeepers with a consistently deadly series of attacks, including the October 1983 suicide attack on a U.S. Marine barracks in Beirut that killed 241 servicemen.

Hezbollah was formed by a group of former seminary students. Many of them had studied in the Shiite holy cities of Najaf and Qom and had subsequently been expelled by either the Iranian government of the Shah or by Saddam Hussein's Iraqi government. In the eastern Lebanese city of Baalbek and later in the poor Shiite neighborhoods of Beirut, they organized mosques, schools and charities, with generous support from the new Iranian Islamist government of Ayatollah Homeini. Between 1982 and 1987 Iran

\footnotetext{
${ }^{9}$ Mitchell (1969) and Armstrong (2000) provide clear accounts of the history of the MB.

10 Armstrong (2000), pp. 241-243. Jihad generally means a personal struggle for piety, self-improvement and service of others (Esposito, 2002, p. 27). Qutb and his supporters argue that Islam is under siege so that violent revolt is an act of self-defense. We thank Timur Kuran for pointing this out.

11 Armstrong, p. 351. The Israel Security Agency estimated foreign support at a million dollars per month in Spring 2003. "Only a fraction" of those funds go to the military wing (ISA director Avi Dichter, Ha'Aretz, July 4, 2003).
} 
spent more than a hundred million dollars annually on hospitals, mosques, schools and charitable organizations affiliated with Hezbollah. Baalbek, which had been a fairly liberal city and a popular tourist attraction in the Bekaa valley of eastern Lebanon, was radicalized over a few short years. Burka, the cloaks worn by traditional Muslim women, became ubiquitous, first in Baalbek, then in the Shiite neighborhoods of Beirut and after that in south Lebanon, as Hezbollah displaced the more secular Shiite Amal movement. Religious radicalization was accompanied by massive increases in social-service provision. ${ }^{12}$ Hezbollah would eventually run candidates in Lebanese elections, becoming the dominant Shia party by 1998 and the core of the pro-Syrian coalition threatening to topple a pro-Western Lebanese government.

While Hezbollah expanded its social-service provision rapidly, it also expanded its territorial control by force, pushing the rival Shia Amal organization out of Shia neighborhoods in a series of battles, sometimes involving artillery. In their confrontations with Israeli forces in South Lebanon, Hezbollah developed and improved many of the tactics that plague coalition troops in Iraq today: roadside bombs, suicide attacks and rocket attacks. They demonstrated their tactical effectiveness in October 2001 and again in July of 2006 with the kidnap of Israeli soldiers patrolling within Israel. When Israel retaliated for that second kidnapping with air strikes within Lebanon, Hezbollah responded with a month of rocket attacks on Israeli civilians. Literally entrenched in positions within southern Lebanon, Hezbollah retained their tactical capacity to fire rockets into Israel despite massive Israeli air strikes, artillery fire and were eventually expelled only by a ground invasion.

\subsection{Taliban, Hamas, Hezbollah}

To summarize, the Taliban, Hamas and Hezbollah are radical Islamic groups that turned violent. While their geographical and theological origins are distinct, they share several functional characteristics which suggest investigating their behavior in parallel. All three formed from affiliates of venerable nonviolent radical Islamic organizations, Hamas from the MB and the Taliban from the Jamiate-Ulema-Islam (JUI) in Pakistan, and Hezbollah from the clerical culture of the Shia holy cities in Iraq and Iran. All three grew by providing local public goods in an environment where local public good provision by government was exceptionally weak. Each developed into an effective insurgent organization that produced a specific local public good - security, using violence. All three received generous subsidies from foreign sources, whose interests and ideologies the organizations furthered. Younger members undergo some costly personal sacrifice in the case of the Taliban and Hamas (we know less about initiation of Hezbollah fighters). There are differences: Hamas and Hezbollah regard all local coreligionists as potential members, while Taliban treated most Afghans as a conquered people. Yet the common elements, common puzzles, and parallels to a wide set of terrorist groups, seem to justify a common framework.

\subsection{Insurgency and suicide attacks}

The Taliban, Hamas and Hezbollah have at different times used both suicide attacks and more conventional forms of insurgent violence. In all three cases their objective is apparently local political power, which Hamas and Hezbollah have pursued through both elections and violence, and which the all three have pursued by capturing territory, just like conventional insurgents. That behavior invites a question: When do rebels choose suicide attacks?

To answer that question it is useful to first review some key facts about insurgencies, and then contrast predictors of insurgency to those of suicide attacks. Insurgency is a technology of rebellion through guerilla warfare that has been successful in challenging regime domination in many countries. It has been hitched to various ideologies: communism, nationalism, religious fanaticism, and perhaps even to no ideology at all (the FARC in Colombia). Between 1945 and 1999, 127 civil wars in 69 different countries accounted for more than sixteen million deaths. ${ }^{13}$ Many of these relied upon the technology of rural insurgency. FL show that civil wars cannot be explained by: (a) level of grievances in the society or (b) degree of ethnic or religious difference or any form of civilizational clash. Rather, the best predictors of civil war are conditions favoring the success of the rural insurgency technology: bad roads, rough terrain, poor state armies, lack of more remunerative employment for young men, and weak or new governments.

\subsection{Suicide attacks as a tactic}

Guerrilla warfare by insurgents encompasses a variety of tactics - most typically a network of self-sustaining rural militias that first intimidate populations and then govern them, providing alternate sovereignty. Suicide attacks - in which the attacker will almost certainly die if the attack succeeds - are here interpreted as a tactic of rebellion distinct from typical insurgency tactics - in which the attacker has at least some chance of survival.

Although they are an ancient tactic in inter-state warfare, suicide attacks are relatively rare. They were not used in modern internal rebellions until 1982 when Hezbollah launched suicide attacks to challenge the Israeli occupation of South Lebanon. The Liberation Tigers of Tamil Eelam (LTTE) in Sri Lanka followed suit with the second major series of suicide attacks taking place beginning in 1987 (combined with conventional insurgency tactics). Suicide attacks occurred in only nine countries in the second half of the 20th century, and in four of those countries only once. Table 1 lists those countries, and also documents the increase in suicide attacks since the year 2000. Data for Table 1 are drawn by combining three sources, two datasets compiled by Robert Pape and a third from the International Policy Institute for Counter-Terrorism in Herzliya. The Appendix to Berman and Laitin (2008) describes these sources and provides details.

\footnotetext{
12 Lebanese sociologist Waddah Sharara called this network the "Hezbollah State" (Shapira, 2000).

13 For a definition of civil war, see notes to Table 1.
} 
Table 1

Suicide attacks by country of perpetrator 1982-2003

\begin{tabular}{|c|c|c|c|c|}
\hline \multicolumn{5}{|c|}{ Panel A: Civil wars and suicide attacks } \\
\hline & & 1946-1999 & & 2000-2003 \\
\hline Countries with new Civil War & & 69 & & na \\
\hline Countries whose residents perpetrated Suicide Attack & & 9 & & 7 \\
\hline \multicolumn{5}{|c|}{ Panel B: Suicide attacks by country } \\
\hline Country & Suicide attacks 1946-1999 & \multicolumn{3}{|c|}{ Suicide attacks 2000-2003 } \\
\hline Sri Lanka & 66 & \multicolumn{3}{|c|}{21} \\
\hline Lebanon & 44 & \multicolumn{3}{|c|}{0} \\
\hline Israel/Palestine & 23 & \multicolumn{3}{|c|}{123} \\
\hline Turkey & 14 & \multicolumn{3}{|c|}{0} \\
\hline Saudi Arabia & 3 & \multicolumn{3}{|c|}{6} \\
\hline Egypt & 1 & \multicolumn{3}{|c|}{0} \\
\hline Algeria & 1 & \multicolumn{3}{|c|}{0} \\
\hline Pakistan & 1 & \multicolumn{3}{|c|}{0} \\
\hline Syria & 1 & \multicolumn{3}{|c|}{0} \\
\hline Iraq & 0 & \multicolumn{3}{|c|}{20} \\
\hline Russia & 0 & \multicolumn{3}{|c|}{20} \\
\hline India & 0 & \multicolumn{3}{|c|}{5} \\
\hline China & 0 & \multicolumn{3}{|c|}{1} \\
\hline Total & 154 & \multicolumn{3}{|c|}{196} \\
\hline
\end{tabular}

Source: Civil war figure from the Fearon-Laitin replication data. Suicide Attack data is from Pape (2003), Pape (2005) and ICT, as described in the Appendix to Berman and Laitin (2008).

Note: FL rely on two datasets: a revised MAR group/country dataset of over 400 minority/ethnic/religious/regional groups in over 100 countries; and a country/year data set of all countries of over 500,000 population in every year since 1945. For replication data see http://www.stanford.edu/group/ethnic/workingpapers/ papers.htm].

Civil war is defined as a violent conflict between an organized militia and the armies of a state, involving contest for control over a region or the entire territory of the state. Enumeration requires at least 1000 deaths recorded as a direct result, concentrated temporally close to its onset, with at least $10 \%$ of the deaths being civilians or soldiers on the government's side. For details see Fearon and Laitin (2003).

Why are suicide attacks so rarely used by rebels? Consider the profile of a suicide bomber as culled from the literature. He (or she) appears to be quite distinct from the typical recruit in a rural insurgency. ${ }^{14}$ The suicide bomber is more upscale economically, and more highly educated on average. The country of his victim is typically richer, and typically has a competent army. The country's terrain is more easily accessed by the state. The list of countries sending multiple suicide attackers is consistent with the idea that suicide attackers come from places where the government and military, or the invading forces, are well organized to suppress insurgency: Israel, Sri Lanka, Lebanon, Turkey, Saudi Arabia, Iraq, Russia and India.

The increase in suicide attacks since 1999 is associated not with increased rebellion but with rebels choosing suicide attacks over other tactics. To illustrate the trend increase in suicide attacks, in the first 4 years of this century 196 suicide attacks were reported, one third more than in the entire second half of the 20th century. While the increase in fatalities is mostly due to the 9/11 attacks, the increased incidence of suicide attacks is almost entirely due to rebellions against well organized, well funded militaries: the second Palestinian Intifada against Israel, the Iraqi insurgency against Coalition forces, and the Chechen rebellion against Russia.

Comparing existing research on insurgencies with that on suicide attacks suggests a conjecture: When conditions disfavor insurgency leaders chose suicide terrorism when possible. The intuition is straightforward. Suicide bombing is a costly tactic, as it strips the insurgent organization of motivated, committed cadres. Moreover, an organization with political aspirations must explain the loss of a son or daughter to the family and community. If sustaining the insurgency were easy, such wasteful losses would be avoided. ${ }^{15}$

To explore the conjecture we combined the FL data on civil wars with the data on suicide attacks, aggregating the latter into country-year observations. ${ }^{16}$ We then compare the predictors of civil war onsets with those of suicide attacks, across countries. Table 2 examines whether predictors of insurgencies also predict suicide attacks. Our measure of insurgency is the one commonly used in the civil war literature, the onset of civil wars. The first two columns reproduce findings familiar from literature (FL; Collier and Hoeffler, 2001). A cross sectional linear probability regression of a civil war onset indicator on GDP/capita and the estimated proportion of mountainous terrain yields a negative coefficient on GDP/capita and a positive coefficient on mountains. ${ }^{17}$ Doubling GDP/

\footnotetext{
14 Krueger and Maleckova (2003).

15 Wintrobe (2006) offers a similar conjecture in discussing the demand side for terror, that is, why leaders would ask for such sacrifices among their closest followers. This reasoning is consistent with the non-use of kamikaze pilots by the Japanese military until American targets were too hard for conventional warfare (Rosenthal, 2003).

${ }^{16}$ How to treat international terrorism? All insurgencies and 91\% of suicide attacks in our samples take place in the country of the attacker (with Israel and Palestine combined). In the $9 \%$ of cases with foreign attackers, including 9/11/2001, we must decide whether the relevant conditions are those of the country of the attacker, the country of the attack, or the country of the target. Since we are interested in the decision between a domestic insurgency tactic and a suicide attack, we code the attack by the country of the perpetrators' organization.

17 We've chosen to report the "between" country estimates rather than use all the variation in the country-year panel to reflect the fact very little of the useful variation is "within" countries. Within country estimates are statistically insignificant once serial correlation of error terms is allowed, for both civil war onsets and suicide attacks.
} 
Table 2

Predictors of civil wars and suicide attacks between country regressions

\begin{tabular}{|c|c|c|c|c|c|c|c|}
\hline \multirow{2}{*}{$\begin{array}{l}\text { Dependent variable } \\
\log (\text { GDP/capita }) \\
\log \text { (Mountains) }\end{array}$} & \multicolumn{2}{|c|}{$\begin{array}{c}\text { Civil war onset (indicator) } \\
1945-1999\end{array}$} & \multicolumn{2}{|c|}{$\begin{array}{l}\text { Suicide attacks } \\
1945-1999\end{array}$} & \multicolumn{2}{|c|}{$\begin{array}{l}\text { Suicide attacks } \\
1945-2003\end{array}$} & \multirow{2}{*}{$\begin{array}{c}\text { Mean of RHS variable } \\
1945-99(\mathrm{SD}) \\
1.10(1.03) \\
2.18(1.40)\end{array}$} \\
\hline & $-0.011(.003)$ & $\begin{array}{l}-0.010(.002) \\
0.0044(.0016)\end{array}$ & $-0.004(.011)$ & $\begin{array}{c}-0.003(.011) \\
0.005(.007)\end{array}$ & $0.01(.02)$ & $\begin{array}{c}0.01(.02) \\
-0.0003(.0139)\end{array}$ & \\
\hline$R^{2}$ & 0.11 & 0.15 & 0.001 & 0.004 & 0.003 & 0.003 & \\
\hline Countries & 161 & 161 & 161 & 161 & 161 & 161 & \\
\hline
\end{tabular}

Note: "Between" country regressions are run by first averaging values for each country over time. Heteroskedasticity-robust standard errors in parentheses. The mean of civil war onset is 0.017 . The mean number of suicide attacks is 0.018 from 1945-99, and 0.046 from 1945-2003. The suicide attacks variable counts suicide attacks in a country-year, where the country is that of the perpetrators. Palestinians are coded in Israel. Results are qualitatively robust to the exclusion of Israel. Results are robust to including indicators for regions of the world and are essentially the same for Tobit regressions.

Source: FL replication data is described in note to Table 1. Suicide attack data is described in the Appendix to Berman and Laitin (2008).

capita predicts a probability of suffering a civil war 8-10 percentage points lower. Doubling the proportion of mountainous regions predicts a 0.44 percentage point lower probability of a new civil war, about one quarter of the mean. These regressions suffer from potential endogeneity bias as discussed in the literature. They are reported here only for comparison. The next two columns, in contrast, show that GDP/capita predicts a small and statistically insignificant change in the number of annual suicide attacks between countries. Mountainous terrain does not predict suicide attacks either. Taken together, these results indicate that the predictors of civil wars do not predict suicide attacks: poor, mountainous countries are no more likely to suffer suicide attacks than richer, flatter countries.

Perhaps the difficulty of conducting conventional insurgency forces the choice of suicide attacks, despite their cost. Israel, for example, suffered from 146 such attacks during the sample period. Israel is a developed, relatively flat, small country with a well equipped army that has invested heavily in information. The conditions for insurgency in Israel, given the FL results, are not propitious. Standard insurgency tactics are unlikely to succeed, making suicide attacks a relatively effective tactic. To further pursue that example, when Hamas - the major perpetrator of suicide attacks in Palestine, turned its sights on the weak military of the Palestinian Authority in Gaza in June 2007, it chose conventional rather than suicide attacks, achieving a quick victory.

Yet not all outgunned rebels in flat countries choose suicide attacks. These cases include South Africa (the ANC), Spain's Basque Country (ETA), Japan (Aum Shinrikyo), Italy (Red Brigades), and Germany (Baader Meinhof). One factor that does predict the use of suicide attacks is, as we mentioned at the outset, a difference in religion between perpetrators and victims. Table 3 presents data confirming this pattern. Overall, $89.9 \%$ of the suicide attacks during our sample period were aimed at victims whose religion was different from the attackers'.

As with the case of the kamikaze pilots (Shinto pilots and largely Christian victims), the suicide attackers in our dataset most often targeted victims of other religions. In Israel (Muslims vs. Jews), Sri Lanka (Hindus vs. Buddhists), Russia (Muslims vs. Eastern Orthodox Christians), and China (Muslims vs. Buddhists), religious difference marked perpetrator from victim. In the nine cases perpetrated by Saudis, although the forces of Al-Qaeda seek to overthrow their coreligionists, their suicide attacks typically targeted Christians. In Egypt, the suicide attack was by Muslim fundamentalists against secular Muslims housed in the Egyptian embassy in Pakistan. Only fourteen attacks perpetrated by the PKK (the Kurds) in Turkey are clearly disconfirming.

To be sure, insurgents target coreligionists much more often than they do members of other religions; they just seldom use suicide attacks to do so. Table 3 reports that only 16.5 percent of civil wars were fought between rebels predominantly from one religious group against armies of a state largely of a different religious group. In three of these cases, suicide attacks were used: Sri Lanka, Russia (Chechnya), and China (Xinjiang). Cases such as Nagorno-Karabakh in Azerbaijan, Srpska Republic in Bosnia, and rebellions in Nigeria, Philippines, Sudan, Cyprus and Bangladesh all pitted guerrilla armies against states led by people of a different religion. In these cases, however, conditions favoring insurgency were better, perhaps lessening the need for expensive suicide attacks. Only the IRA in Northern Ireland is an example not promising for insurgency, along with religious difference, yet no suicide attacks. Hezbollah, Taliban and Hamas often attack coreligionists themselves, though never with suicide attacks.

Taken together, the evidence in Tables 1, 2 and 3 shows that insurgencies are predicted by very different factors than are suicide attacks. Insurgents tend to operate in poor, mountainous regions and against coreligionists. Suicide attackers tend to come from countries that are not particularly poor or mountainous and they tend to attack members of other religions. While much has been made of the radical Islamic aspect of suicide terrorism, the greatest wave of suicide attacks in the 20th century was by (nominally atheistic) neo-Marxist Tamil separatists against the Hindu Sri Lankans. Yet even putting aside radical Islam, the evidence of religious difference in suicide attacks in Table 3 is extremely strong and requires some explanation.

In the next section we develop a framework based on economic clubs to explain why religious radicals are so successful as rebels fighting well-armed states. We augment that model with a tactical analysis of suicide attacks to address the patterns in Tables 1, 2, and 3. Our approach, which is much more mundane than the grand theme of civilizational conflict, is tested in Section 4.

\section{Rational martyrs and terrorist clubs: a framework}

Why are religious radicals such successful rebels? Why do they so often choose suicide attacks? And why are members of other religions so often the targets of those suicide attacks? The conventional answers rely on theology: promises of eternal grace motivate radical religious rebels to battle fiercely. Rewards in the afterlife will compensate them for losing their lives in suicide attacks, but not if they kill coreligionists. Recalling the discussion in the introduction, careful work in psychology and political 
Table 3

Religious differences between perpetrators and targeted victims

\begin{tabular}{lll}
\hline & Insurgency & Suicide attack \\
\hline Proportion with religious difference & $87.4 \%$ \\
(Standard error) & $16.5 \%$ & $(3.6)$ \\
\hline
\end{tabular}

Note: An observation is a country-year in the middle column and a single attack in the right column. An insurgency is measured by the onset of a new civil war, as in Table 2. FL replication data is described in note to Table 1. Suicide attack data is described in the Appendix to Berman and Laitin (2008).

science has largely rejected those notions: suicide attackers do not appear to be motivated primarily by religious beliefs, and religious radicals often kill coreligionists - though by other means. So rather than focusing on theological motivations we model a rebel organization with rational members, whose payoffs could be in the hereafter. We analyze the unique agency problems that an organization has in providing public goods (both violent and nonviolent) and consider how it chooses among violent tactics. ${ }^{18}$

\subsection{Rational martyrs? ${ }^{19}$}

Judging by press coverage, much of the terror generated by terrorists attacks comes from the idea of an army of theologicallymotivated suicidal drones. Yet suicide attackers could be rational. That would require either: a) a belief that their suicidal act will be rewarded in the hereafter; or b) altruism toward family or compatriots combined with a belief that the suicidal act will benefit family, community or some larger cause (Elster, 2006; Pape, 2005); or c) a desire to maximize social solidarity achieved by sacrificing one's autonomy for group goals (Wintrobe, 2006).

A given population is likely to contain at least some individuals who hold the necessary beliefs and preferences. Belief in the hereafter and in rewards in the hereafter is widespread. Islam, like all major religions sanctifies human life and rejects suicide. ${ }^{20}$ Yet Qutb justified suicide attacks as a sacred defensive act of Jihad. So while mainstream religious beliefs preclude suicide, aspects of religion could be useful in recruiting a suicide attacker who was so inclined.

Preferences for altruism or group solidarity, combined with a belief that the welfare of others will be improved by the act, may apply to both religious and secular terrorists. Recall Merari's interviews with failed Palestinian suicide attackers and families of suicide terrorists, which suggested that religiosity and promises of rewards in the afterlife were not their main motivating force. If anything, altruism seems to be a more likely motivation. For suicide attackers altruism would need to be accompanied by an exaggerated belief about the benefit to their cause resulting from a successful attack. For instance, the 9/11 terrorists may have believed that their act would help topple the Saudi government. A Hamas suicide bomber might believe that a single destructive act would significantly contribute to creating an Islamic state in Palestine. These beliefs stretch credulity but reflect a common bias of decision-makers in overestimating their potential to affect change (Jervis, 1976). The belief that through suicide one can experience the ultimate oneness of individual and group goals, as suggested by Wintrobe (2006), is also plausible.

While we lack estimates of the incidence of different beliefs, only a very small proportion of the population need be committed believers if an organization can identify and recruit them. Iannaccone (2006) points out that despite conventional wisdom about "brainwashing," research reveals that indoctrination played only a minor role in recruitment to US sects in the 1970s. Recruits were predisposed to belief. Thus it may not be difficult to find volunteers who prefer martyrdom to life, even without indoctrination or radical religious beliefs. That is disturbing, considering how easy it is to train and arm terrorists for extremely lethal attacks. Yet only a few organizations in the world have managed to activate suicide attackers and consistently carry out attacks. ${ }^{21}$ Of those most (though not all) are religious radicals. So what is so hard about organizing suicide terrorism and why are religious radicals so effective at it?

\subsection{Prohibitions and sacrifices among religious groups in general}

To explain the puzzling effectiveness of religious sects when they rebel, and their choice of suicide tactics, we turn to the sociology of religion and draw on a theory developed to explain Christian and Jewish sects. Sects (and even mainstream denominations) pose a puzzle for rational choice theory: they prohibit common pleasurable behaviors and require sacrifices. Prohibitions involve food, Sabbath activities, dress codes, driving licenses, sexual practices, and medical care, for instance. Sacrifices are an irreversible destruction of resources, such as burnt offerings. In the recent history of European Jewry, circumcision irreversibly labeled a child as Jewish, an act that might put his life at risk by destroying the option of disguising him as a gentile. A vow of fidelity or abstinence is also a form of sacrifice, as it represents a permanent restriction of activities. Years of volunteer work required of Mormons can be thought of as a sacrifice of time, especially considering the foregone opportunity to accumulate human capital. Years of study in a religious institution sacrifice alternative potential uses of that time - accumulating human capital in secular studies or accumulating earnings and work experience.

\footnotetext{
18 See our review of Pape (2005), Bloom (2005), and Gambetta (2006) in Berman and Laitin (2007).

19 This discussion owes most of its content to a conversation with Larry Iannaccone.

20 Neither Christianity nor Judaism has consistently extended that sanctity to civilians of other religions. Samson, who clearly targeted civilians, is memorialized as a martyr by both Jews and Christians. Berman (2003) and Berman (in press) discuss discusses Christian and Jewish religious militias.

21 At this writing the U.S. State Department lists only 42 designated terrorist organizations in the entire world. Why so few? Asal and Rethmeyer (2008) investigate organizational predictors of lethality. Shapiro and Siegel (2007) examine organizational constraints which limit lethality.
} 
Limiting choices and destroying resources is puzzling to an economist, yet people voluntarily join groups that enforce prohibitions and require sacrifices. These groups stubbornly defy price theory, persisting in time-intensive activities like communal worship, Sabbath observance and intricate food preparations, despite the historical increase in the shadow price of time. Strict sects show no sign of disappearing and those with the most demanding practices seem to be growing fastest. The modern Anabaptist traditions (such as the Amish, Mennonites and Hutterites) are holding their own while ultra-orthodox Jewry, and radical Islam are thriving, despite a multitude of time-intensive requirements. Iannaccone (1992) offered a creative solution to the puzzles of prohibitions and sacrifices, proposing that they are efficient institutions in the context of an economic club that provides services to members. We present a simplified version of his analysis and then extend it to cover coordinated violence by clubs.

\subsection{Efficient prohibitions}

A social interaction model offers an explanation for prohibitions and sacrifices. Group members derive utility from (secular) consumption, $S$, and from time spent in religious activities, $R$, such as prayer and community service. They also gain utility from the level of a local public good $A$.

$$
U_{i}=U\left(S_{i}, R_{i}, A\right) \text { for } i=1 \text { to } N \text { members, } \quad U_{1}, U_{2}, U_{3}>0, \quad U_{11}, U_{22}, U_{33}<0 .
$$

Good $A$ is partially nonrival and excludable, making it a club good. Members get $A$ from either a government, $G$, or the "club," $C$, which uses hours of religious activity as an input. Public safety is an example of a pure public good that could be provided by government or by a club, perhaps as a religious obligation. Welfare services, schools, hospitals and mutual insurance are examples of excludable, partially rival activities commonly provided by religious sects. ${ }^{22}$

$$
A=G+C\left(\left\{R_{i}\right\}\right), \frac{\partial C}{\partial R_{i}}>0 \text { for all } i
$$

Members maximize utility subject to time and budget constraints. A fixed allocation of time, $T$, is split between the religious activity, $R$, and work hours, $H$,

$$
T=H_{i}+R_{i}
$$

Income is earned from wages $w$ and spent on consumption of the secular good, $S$, at price $p$,

$$
p S_{i}=w H_{i}=w(T-R) .
$$

A key point is that the club good $C$ is produced by voluntary donation of time by members. These donations are extremely common in religious sects. Since that voluntary activity generates positive externalities, competitive equilibrium will result in too little religious activity $R$, (assuming solutions on the upward sloping part of a labor supply curve). That is, the competitive equilibrium choice of work hours, $H=T-R$, at the wage $w / p$ ignores the marginal rate of substitution between A and $\mathrm{S}$ in the optimality condition for the efficient labor supply that a social planner would choose. She would prefer less work and more religious activity (at $R^{*}$ ).

$$
\frac{w}{p}=\frac{U_{2}}{U_{1}}+\frac{U_{3}}{U_{1}}=M R S_{R S}\left(R^{*}\right)+M R S_{A S}\left(R^{*}\right)
$$

A community without tax authority ${ }^{23}$ could achieve the optimal level of religious activity ( $\left.R^{*}\right)$ by imposing and enforcing prohibitions on types of secular consumption, inducing members to work less and spend more time at religious activities. Thus religious prohibitions can be rationalized as extreme but enforceable forms of taxation on secular activity. Individuals will voluntarily join a club that requires prohibitions if the extra club good produced with the additional hours, $N x\left(R^{*}-R\right)$, is sufficiently valuable. More generally, contact with the secular world substitutes for club activities. Prohibitions that limit outside contacts induce members to spend more time in religious and other club activities that have positive externalities. Exclusion from access to the local public good $C$ is a common, viable form of enforcement.

This argument can rationalize many forms of religious prohibition. For example, dietary restrictions increase the cost of market provision of food, while decreasing the ability of group members to socialize with nonmembers. Sabbath restrictions preclude driving to the mall and consuming, inducing members to spend time together on the Sabbath instead, and so forth. This also explains the logic of dress codes, which aid enforcement by making community members readily identifiable. As in the military, being caught out of uniform triggers sanctions. ${ }^{24}$

\footnotetext{
${ }^{22}$ We assume that a nondiscriminatory government provides services without regard to affiliation.

${ }^{23}$ A community with tax authority would subsidize $R_{i}$, or tax the alternative use of time, $H_{i}$. Religious groups often encourage $R$ with eternal promises and the respect of one's peers. Yet $R$ may be hard to subsidize if it is unobservable, like anonymous charity. A community that can literally control the price level faced by members with taxes can achieve the social welfare optimum by imposing a tax $\tau=p^{*}-p$, which induces a choice of $R^{*}>R$.

24 Adam Smith (1776, reprinted 1965) used the term "sect" to describe 18th century Christian religious groups with strict practices. Sociologists use that term for groups that strongly restrict secular activities (Weber, 1978). Smith could just as well have been describing the birth of ultra-orthodox Judaism in the late 18th century, or of radical Islam in the early 20th.
} 
Friction between club members and nonmembers resulting from a club's political agenda, for instance, may cause antagonism toward club members. That antagonism can be desirable and efficient for the club if it discourages outside activity by members. It provides another mechanism to induce higher levels of religious activity by reducing outside options. In that sense this is a theory of efficient intolerance. Efficient mutual antagonism between two clubs is an immediate extension. ${ }^{25}$

\subsection{Efficient sacrifice}

Rationalizing prohibitions helps explain how radical religious sects operate, but our insights into rebel organizations flow from understanding sacrifices - acts that irreversibly destroy value, such as circumcision, burnt offerings, or ritual bloodletting. They cannot be rationalized as efficient prohibitions following the argument above as they do not tax a secular activity. They can be explained as an initiation rite which signals type (Camerer, 1988; Iannaccone, 1992).

To see how the model explains sacrifices, augment it with unobserved heterogeneity: high wage (type 2) and low wage (type 1) individuals. High wage individuals choose less religious activity as it is relatively more expensive for them, i.e., $R^{2}<R^{1}$. (Heterogeneity could alternatively be in both preference for religious activities at the margin or in wages. Heterogeneity in wages alone is chosen mainly to simplify the exposition.) Assume that the value of the club good is given by the average of $R$, as would plausibly be the case in a mutual insurance club where average donation of time by members to mutual aid would matter.

$$
C\left(\left\{R_{i}\right\}\right)=C(\bar{R}), \quad \bar{R}=\sum_{i=1}^{N} R_{i} / N
$$

High wage - low $R$ individuals are potential "free-riders." They would like to join the high $R$ club and benefit from their high average level of religious activity. Members of the high $R$ (low wage) club would rather not admit the high wage types, as the reduction in the average level of religious activity will reduce club quality. Since access to the externality is excludable, the high $R$ (low wage) group can rid their club of free-riders by requiring a costly initiation rite, or sacrifice of time, $\kappa$, which will successfully exclude low $R$ (high wage) individuals from joining, keeping $C$ high, at $C=R^{1}$. Unlike religious activity, $R$, the sacrifice benefits no one except through its role as a signal. Potential applicants are forced to reveal their type, which is otherwise unobservable, when they make a decision to sacrifice, or not to sacrifice, time.

A membership requirement inducing only low wage types to sacrifice can be a separating equilibrium. (See Berman, 2000 for a formal derivation and conditions.) The efficient sacrifice is the smallest $\kappa$ that induces separation, leaving high wage types indifferent between the high $C\left(R^{1}\right)$ and sacrifice, and the low $C\left(R^{2}\right)$ without sacrifice. The low wage, high $R$ group is better off with the institution of a sacrifice and will accept anyone who makes the sacrifice into the group, since a sacrifice reliably signals a high level of religious activity. This setup is analogous to other forms of costly sacrifices that signal type, such as initiation rites in the military, hazing in fraternities, or signaling in schooling (Spence, 1973).

This view of religious sects as social-service provision clubs has testable implications. The stronger the sacrifice demanded of members, the higher the average level of voluntary religious activity and the greater the degree of mutual insurance. That implication is confirmed in Iannaccone's (1992) study of Christian denominations and supported by Berman's (2000) study of ultra-orthodox Jews. Among Muslims at least some radical sects are active at social-service provision, including Hamas, the Hezbollah, the MB in Egypt (Mishal and Sela, 2000; Munson, 2002), and Muqtada Al Sadr's Mahdi Army in Iraq. Other testable implications of the club approach to religion are supported by evidence on Indonesian Islamists (Chen, 2003) and Muslims with children in religious schools (Berman and Stepanyan, 2005).

Applying this model to the behavior of radical Islamic groups yields some immediate insights. It allows us to rationalize the common Taliban practice of years of attendance in religious seminaries that offer little or no training in marketable skills (or even combat skills). While indulging in the study of holy texts might not be surprising as a leisure activity for relatively wealthy individuals, it is a puzzling choice for impoverished Afghan refugees in Pakistan. Yet, as a sacrifice of time which allows access to a desirable club, that behavior may be quite sensible. ${ }^{26}$ The puzzling sacrifice among Hamas is of a different nature. Members show a surprising willingness to risk arrest by organizing and conducting low level violent activity. Since arrest often implies protracted jail terms, this activity can also be understood as a sacrifice of time. Suicidal acts are not a sacrifice in this context as there is no subsequent action for which the signal of commitment is useful. We return to suicide attacks below.

Why do radical religious groups so often create rebel organizations and why are those rebels so effective? Define militia activity as coordinated capture of economic or political rents using violence. Attacking an occupying army, providing law and order, organizing and carrying out clandestine activity (such as terrorism) are examples. This activity involves personal risk. A key aspect of militia activity is its sensitivity to defection. This section argues that religious sects have an advantage in militia activity because the signaling mechanisms adopted for the provision of other public goods allow them to select members unlikely to defect in a militia.

\footnotetext{
25 While it could be efficient for each club, mutual antagonism may endanger innocent bystanders.

26 Interpreting protracted Maddraseh attendance as a sacrifice assumes that young Afghans in refugee camps had more productive educational or work opportunities available. In other places we know that alternative schooling is available (Berman and Stepanyan, 2005). In Afghan refugee camps in Pakistan the productive alternative is likely work. An alternative interpretation is that Maddraseh attendance did not signal low market opportunities, $w_{i}$, but actually caused them. That variant of the model has the same testable implications, though the sacrifice interpretation is more palatable ethically and more consistent with concern sects show about "commitment."
} 


\subsection{Securing a trade route}

Consider a standard assignment in the imposition of law and order, securing a trade route. Imagine a road with $N$ checkpoints at which a convoy can easily be robbed, such as the Kandahar-Herat route. Assume that the convoy is worth $B$ at the last stop but worth nothing at the first, to emphasize gains from trade.
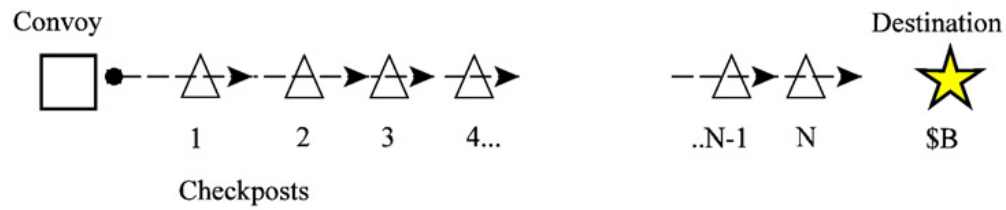

\section{Securing a Trade Route}

A club member at each checkpoint allocates time to either $R$ or $H . R_{i}+H_{i}=1$ and $R_{i}$ is binary. Member $i$ can either "defect" $\left(R_{i}=0\right)$ and steal $B$ or remain "loyal" $\left(R_{i}=1\right)$ and protect $B$. The public good technology is

$$
\left.C\left(\left\{R_{i}\right\}\right)=C\left(\prod_{i=1}^{N} R_{i}\right)\right)
$$

where $C(1)$ is the value of a safe road and $C(0)$ is that of an unsafe road, so that $C(1)>C(0)$. This multiplicative technology for joint production differs from the club's technology for producing benign local public goods, which averaged the $R_{i}$, in Eq. (3).

A convoy will choose to set out only if all $R_{i}$ equal 1 , which is to say each member chooses loyalty. In that case the convoy reaches the last stop and the club extracts the entire surplus $B$, which it shares equally among members, each receiving $B / N P$. If member $i$ defects he keeps the entire surplus $B$, loses access to the safe road (the public good $C$ ) as punishment, but earns the outside option wage $w_{i}>0$. That member will remain "loyal" if the following incentive compatibility constraint holds:

$$
U\left(\frac{B}{N P}, 1, G+C(1)\right) \geq U\left(\frac{B+w_{i}}{P}, 0, G\right)
$$

Taking the terms in the utility function in order, a loyal member has lower consumption than a defector $(B / N P<(B+w) / P)$ but gains the direct utility from doing his (religious) duty $(R=1)$ and has access to more of the local public good since $G+C(1)>G$. If incentive compatibility fails, the route is an $N$ player prisoner's dilemma, resulting in no convoys and no rents to extract.

Now consider heterogeneity and adverse selection. Assume two unobserved types, high wage and low wage (as above) and assume parameter values such that low wage types remain loyal and high wage types defect. (I.e., there exists a $w^{\prime}$ such that $w^{L}<w^{\prime}<w^{H}$ and incentive compatibility in Eq. (5) holds only if $w_{i}<w^{\prime}$ for all $i$.) A club with a costly sacrifice as an initiation rite, which successfully excludes all high wage types, can consistently secure the trade route and extract the rent, $B$. A militia that cannot exclude high wage types will fail to secure the route.

Fig. 1 illustrates that the maximum project value is higher for militias who can exclude high wage members. ${ }^{27}$ It plots utility against the value of the convoy or target, $B$. If members sufficiently value the benefits of the club good and of the religious activity then at low project values it is easy to construct parameter values such that loyalty dominates defection, as illustrated. ${ }^{28}$ As $B$ increases, the value of defection increases more quickly than that of loyalty since defectors retain all of $B$. This implies a maximum incentive-compatible project size, $B^{*}$, where defection still dominates loyalty. For larger projects than $B^{*}$ members will defect.

Militias prefer lower wage members because they are less prone to defection. Since loyal members $\left(R_{i}=1\right)$ earn no wages, their utility is unaffected by their wages. High wage defectors have higher utility than low wage defectors at all project values. In the interval $\left(B^{*}, B^{* *}\right)$ high wage members will defect while low wage members will remain loyal. This would explain the advantage of building a militia of young men with little labor market experience who were educated in the Maddraseh of Afghan refugee camps, rather than choosing combat veterans from among former Mujaheddin. It also explains why, once formed, the Taliban are so successful. ${ }^{29}$

The multiplicative technology in Eq. (4) generally describes a wide variety of militia activities in which success is critically dependent on the loyalty of all members. Moreover, in cases where members endanger themselves, survival may depend on the loyalty of others. We now consider two further examples of militia activities: coordinated assaults and clandestine attacks.

\footnotetext{
27 These figures illustrate the "single crossing" case in which utility curves of loyal members and defectors intersect only once, so that there is at most one incentive compatible range of project values for loyal members. Monotonicity of $U$ in all three arguments allows multiple crossings if complementarities are extreme. Only one of our testable implications relies on single crossing, as noted below. The remaining analysis requires ruling out only the extreme case in which an attack that does infinite damage $(B)$ is incentive compatible for loyal members, as that attack would always be chosen by utility maximizers.

${ }^{28}$ The figures are simulated using utility function $U(S, R, A)=\left(S^{\beta} R^{\beta} A^{\beta}\right)^{1 / \beta}, \beta=1 / 3$.

29 The model is presented as static for simplicity. Berman (2003) sketches the dynamic case.
} 


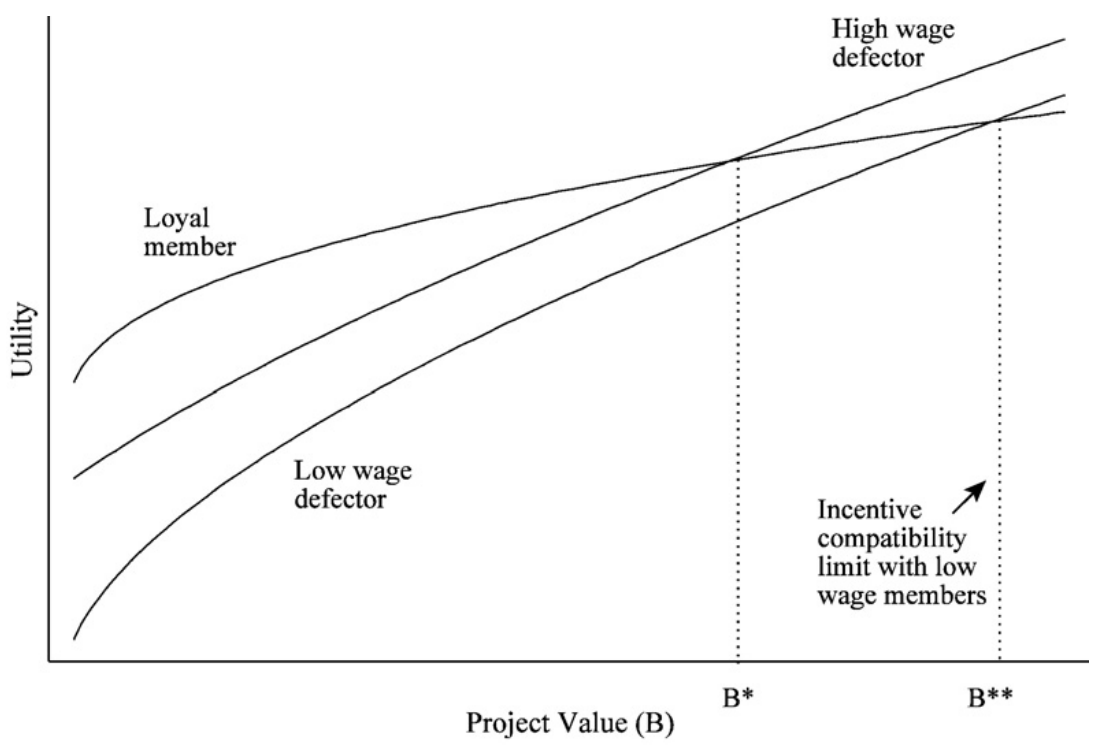

Fig. 1. Low wage membership allows high-value projects.

\subsection{Coordinated assault}

Another example of militia activity relevant for Afghanistan is coordinated assault, the essential element of ground warfare which the Taliban were surprisingly adept at. Soldiers (or units) attack some target by alternating between advancing and providing cover fire. Defection by the unit providing cover leaves other units exposed to fire from the target, causing the assault to fail. Assume that the target is worth $B$, both to the attacker and to the potential victim. Assume also that $B$ can be divided as income among attackers (as would literally be the case for mercenaries). The potential victim will be willing to pay up to $B$ to induce defection, a common occurrence in Afghanistan. A successful assault is a club "good" to members, perhaps because it rids them of some occupier, enhancing their quality of life. The analysis is then formally identical to the trade route case above, with militia production described by Eq. (4), the same payoff structure, and an assault succeeding only if the incentive compatibility constraint (5) holds. ${ }^{30}$ If Eq. (5) fails, no assault is carried out and no rent is captured.

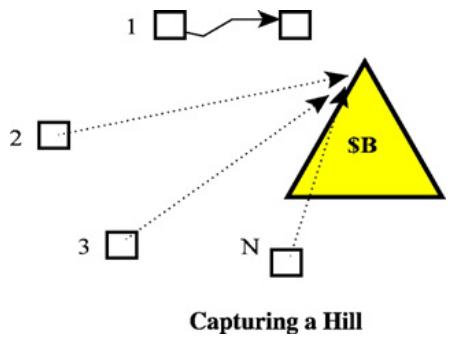

In Afghanistan, this approach resolves the puzzle of how the inexperienced Taliban successfully secured trade routes for Pakistani interests and controlled territory while combat-hardened warlords and former Mujaheddin could not. Groups less adept at extracting signals of commitment (sacrifices) may not be able to consistently enforce incentive compatibility. The more radical the religious group in its norms of sacrifice (in this case protracted Maddraseh attendance), the lower the effective outside wages of members and the more capable it is of capturing and controlling territory in the face of possible defection by members.

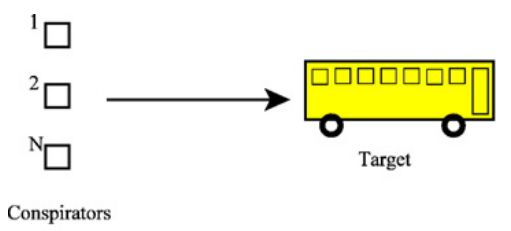

Terrorism

\footnotetext{
${ }^{30}$ Considering the danger we could relax the zero-sum assumption and allow the victim to lose more than $B$ from an assault. That exacerbates the incentive to defect as the victim will be willing to pay more than $B$ to a defector.
} 


\subsection{Terrorism}

Clandestine militias such as guerrillas and terrorists also share the multiplicative technology in Eq. (4). Consider an attack on some civilian target, perhaps using a remote-controlled bomb. The government protecting potential victims can induce defection by offering a bribe at any stage in the process, from planning through the moment of attack. Any of $N$ conspirators can defect or remain loyal. (This may be a negative sum activity. The replacement value of damage to the victim, $D$, may far exceed the value to conspirators, $B$, so that $B<D$, even if $B(D)$ is an increasing function.) Assume that the $N$ conspirators have nonrival benefit $B$ from a successful attack. Assume also that conspirators have income from some outside sponsor (who values $B$ ). That income is small but proportional to $D, \alpha D$, where $0<\alpha<1$. Assume for simplicity that a defector can extract the entire surplus, $D$, from the potential victim. The incentive compatibility constraint for a member is then

$$
U\left(\frac{\alpha D}{N P}, 1, G+B+C(\bar{R})\right) \geq U\left(\frac{D+w_{i}}{P}, 0, G\right)
$$

As in the other examples of militia activities, a member remains loyal if the intrinsic value of doing his duty $(R=1)$, and the benefit of the extra local public good, $B+C(\bar{R})$, are sufficient compensation for the foregone income $((D+w) / P-\alpha D / N P)$ available to defectors. We assume that in this case the club is producing two substitute local public goods, $B$ and $C$, each with a different production function.

Now consider again heterogeneity in outside options, $w$. Assume parameters are such that members with good outside options will defect while low wage types will not (a wage $w^{\prime}$ exists below which (6) will hold and $w^{L}<w^{\prime}<w^{H}$ ). A club that extracts signals of commitment can implement the attack technology (Eq. (4)) while militias without signaling cannot.

\subsection{Comparative statics - strong clubs}

Fig. 2 illustrates how any increase in the value of the benign club good, $C$, expands the ability of the club as a militia. As in the previous figure, the maximum incentive-compatible project has value $B^{*}$. A member who was on the margin of being bribed into defection at $B^{*}$ will be induced to remain loyal by the attraction of an augmented benign club good, represented by the vertical shift in the utility of a loyal member. A much larger potential bribe, $B^{* *}$, is now required to induce defection. Augmenting the benign club good increases militia activity. For a given $B$ in the range between $B^{*}$ and $B^{* *}$, loyalty can be induced in Eq. (6) where it was previously absent, allowing rent extraction (in the convoy example) to increase from zero to $B$. If the club chooses projects, (i.e., convoys to allow on the road, hills to capture, targets to attack) it can expand its feasible range of projects from $\left(0, B^{*}\right)$ to $\left(0, B^{* *}\right)$, capturing larger rents.

Thus clubs that are more productive at a benign activity can exploit the induced cohesiveness by allowing themselves more militia activity, in the sense of a higher project values $B$. In this way efficient provision of nonviolent club goods, such as health care, mutual insurance or educational services, complements the ability of these same clubs to function as militias. The figure illustrates a first testable implication of the club model of terrorism. Terrorist organizations providing social services can attack higher value targets without fear of defection. We test that prediction below using data from the Middle East.

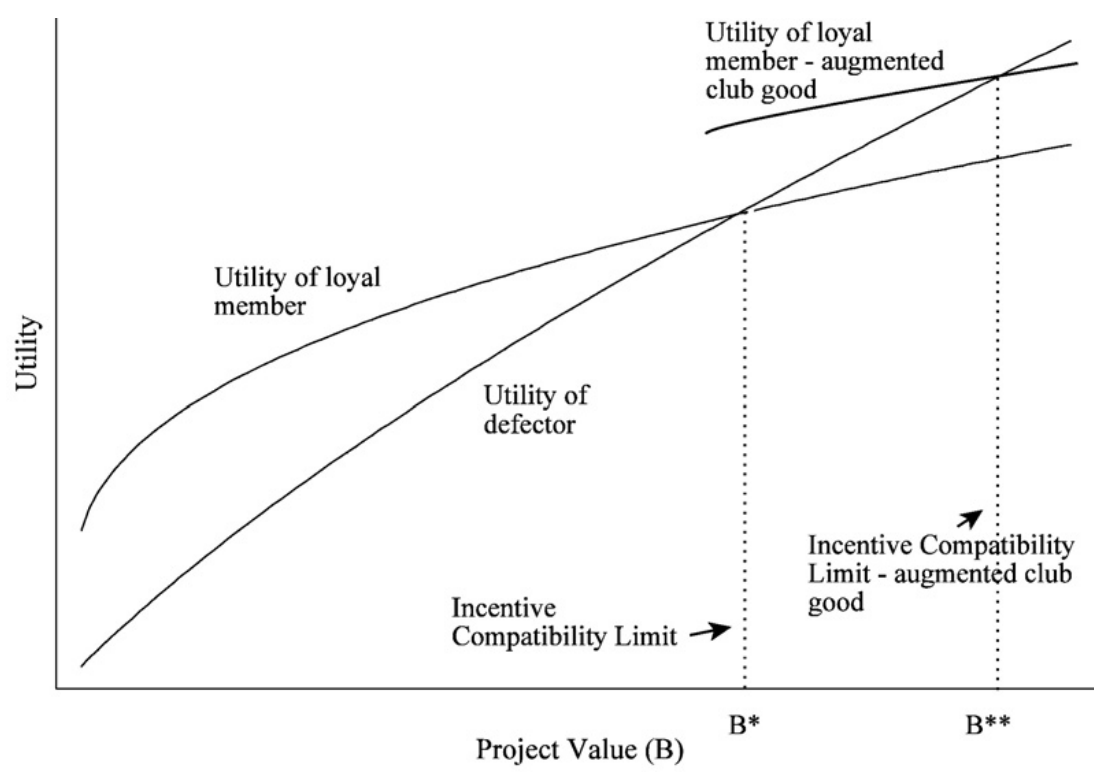

Fig. 2. Benign activity increases a militia's potential. 


\subsection{Suicide attacks}

Terrorism evokes the painful topic of suicide attacks, which we approach here as a tactical choice. Much of the interest of social scientists in suicide attacks has focused on the rationality of the attacker and the sense of vulnerability that suicide attacks create, both of which we've discussed above. From the point of view of operatives, though, suicide attacks have two very attractive features: first, they effectively deliver a weapon to the location where it can do the most damage; second, they protect operatives, since the suicide attacker cannot leak valuable information after the fact, preserving the identities and location of operatives.

Why do some environments produce conventional insurgencies while others produce suicide attacks? Recalling Table 3, one predictor of suicide attacks is targets of another religion. Hamas, Hezbollah, the LTTE, the Taliban and other terrorist organizations that use suicide attacks against civilians of other religions often kill collaborators and political rivals of their own religion. Yet they almost never use suicide attacks to do so.

Consider the characteristics of coreligionists as targets. They are "soft" targets in a very important sense. The typical problem in defending ("hardening") a target, especially in a crowded place, is the infeasibility of screening all individuals with access to the target for every possible weapon. One solution is to predict which individuals are at highest risk of harboring violent intentions ("profiling") and then screen them carefully - examining them for weapons. Yet coreligionists are typically similar in appearance, often sharing common language, dialect and even accent, making profiling coreligionist attackers extremely difficult. ${ }^{31}$ When profiling is difficult a terrorist can often walk up to a civilian victim, shoot him and escape into the crowd, as the gentleman WilkesBooth did to President Lincoln.

Besides profiling attackers, another way to harden targets is to invest resources in their protection, such as inspections at airports, security guards, and the surveillance of probable threats. In the few prominent cases of suicide attacks on coreligionists, targets were well-defended by means beyond profiling. That was the case in the assassination of Egyptian President Anwar Sadat by the Egyptian Islamic Jihad, which was essentially suicidal, and in the assassination of Northern Alliance leader Ahmad Shah Massoud by Al-Qaeda suicide bombers disguised as journalists (Rashid, 2002, p. 87). ${ }^{32}$

The notion of hard targets can also explain the patterns in Table 2. Countries with high-income per capita have governments with sufficient resources to protect military targets against attack by standard insurgency tactics, thus preventing a conventional insurgency from succeeding. The Hobbesian argument offered by FL can be restated in our terms. Well-funded military and police forces that control their own territory provide hard targets. They are capable of eventually finding, capturing and interrogating attackers. Under interrogation captured cadres will generally reveal information about the insurgency, further undermining the organization. Mountainous terrain, then, is important because it is so difficult for even a strong government to control, allowing rebels attackers a refuge even if their identities are known. Rebels opposing poorly funded governments or based in mountainous areas are more likely to attempt an insurgency, but no more likely to resort to suicide attacks.

\subsection{An analytical approach to terrorist clubs and suicide attacks}

To analyze when suicide bombing is the chosen tactic, we introduce the possibility of apprehension. Let $p$ be the probability that the attacker is caught, and assume that apprehension exposes the identity of all operatives, implying both a failed attack and capture or death for all operatives. ${ }^{33}$ We (prosaically) describe that outcome as setting utility to zero for operatives. An apprehended attacker is thus far more dangerous for the organization than a deceased attacker.

Consider the conventional attack. Apprehension probability is a function of the inherent "hardness" of the target, $p(h)$. The difficulty, or "hardness," of the target is denoted by $h$, an index of defensive measures by the target (or its government) and topography (as in FL 2003). Targets can increase $p$ by investing in protective measures, increasing $h$. The expected utility of an operative from a conventional attack in the model including apprehension probability is

$$
[1-p(h)] U\left(\frac{\alpha D}{N}, 1, G+B(1)+C(\bar{R})\right) .
$$

In contrast, the utility of an operative from defecting is

$$
U\left(D+w_{i}, 0, G\right) .
$$

These choices are illustrated by the solid lines in Fig. 3, which graphs the utility of operatives on the vertical axis and damage done to victims on the horizontal axis. ${ }^{34}$ The steep bold curve is the utility gained by defecting Eq. (7b). It increases most quickly in

\footnotetext{
31 This might explain the anomaly of Northern Ireland, where suicide attacks are not used, even against members of the other religion. Diego Gambetta (personal communication, October 21, 2003) reports on research showing the strategic mimicking of identities so that potential targets of terror avoid identification as either Protestant or Catholic. These strategies hinder profiling, perhaps making suicide attacks unnecessary.

${ }^{32}$ In both cases the attackers overcame any theological objections to killing Muslims. They may well have chosen the suicide tactic because a conventional attack implied almost certain apprehension or death anyway. Similarly with the LTTE assassination of Rajiv Gandhi on May 21, 1991, in which a Hindu killed a Hindu. As the favorite to win election as Prime Minister of India, he was extraordinarily well-defended.

${ }^{33}$ We've simplified the analysis by assuming away two possible intermediate outcomes: (1) not destroying the target and escaping; and (2) destroying the target without escaping. In the first case a risk was taken but nothing happened. The second case is almost as negative as complete failure for operatives, as a captured attacker will most likely reveal enough information to expose them, leading to their likely capture or death. Considering these outcomes adds little to the analysis except to highlight a major advantage of the suicide attack - there is no attacker to interrogate.

${ }^{34}$ Figures can be generated with simulated utility functions for specific parameters. Non-negative utility is assumed.
} 


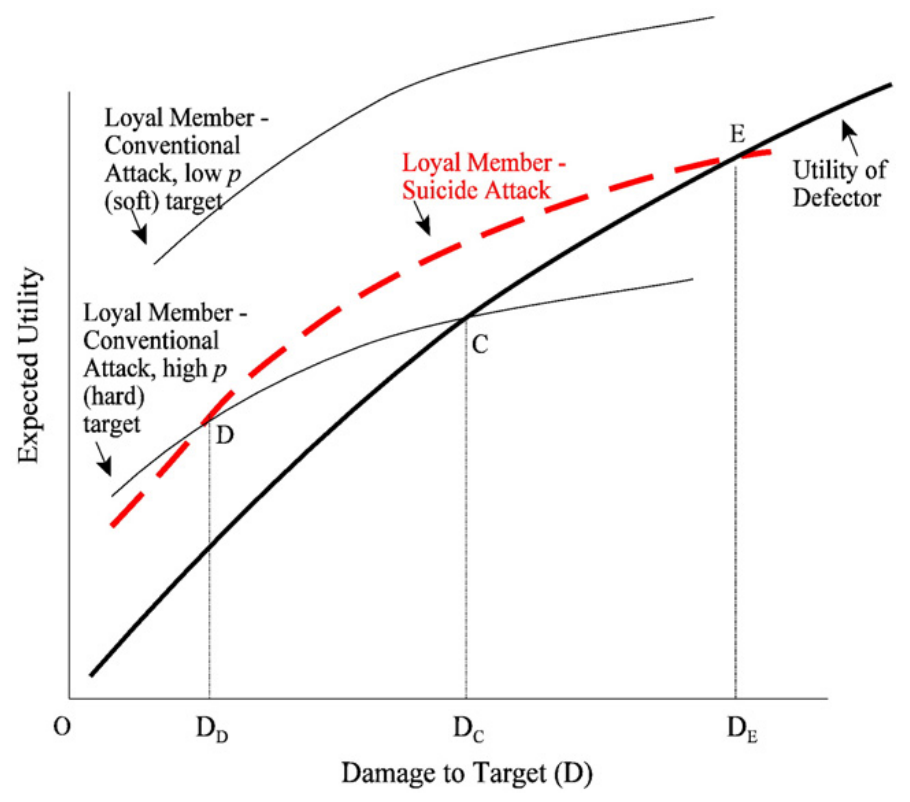

Fig. 3. Conventional attacks, suicide attacks and damage.

damage, $D$, because the full value of $D$ is available to induce operatives to defect. It begins at a low level, for low $D$, because defectors draw no local public goods $(B$ or $C$ ) from the club.

For "soft" targets with a low probability of apprehension the utility of a loyal member Eq. (7a) from a conventional attack is represented by the upper solid curve. Utility for loyal operatives using the conventional attack is high even at low $D$ because they benefit from club goods $B($.$) and C($.). It increases slowly in $D$ because the subsidy is only $\alpha D(<D)$ and is split among $N$ operatives. For low probability of apprehension conventional attacks and loyalty are chosen over defection for the entire range of damage $(D)$ in the figure.

Hardening targets (i.e., increasing the probability of apprehension, $p$ ) reduces the expected utility for loyal operatives from a conventional attack, as the figure illustrates by the downward shift in the expected utility of a loyal operative. With high $p$ the conventional attack is incentive-compatible only for a narrow range of targets $\left(0, D_{C}\right)$ for which expected utility from an attack ( $\left.7 a\right)$ exceeds that from defection (7b). In this way the model captures an important finding in the insurgency literature: factors that raise $p$, such as topography, strong government, and easily-profiled rebels, limit the targets that an insurgency can aspire to attack without operatives defecting (FL). Conventional insurgency is then limited to low damage activities.

For hard targets (high apprehension probability) suicide attacks become relevant. They are less dangerous for the operatives (besides the attacker) but require them to lose a committed cadre and compensate a bereaved family, which we represent as a cost $-Z$ lost in a nonrival way by operatives, a club bad. Utility for an operative from a suicide attack is then

$$
U\left(\frac{\alpha D}{N}, 1, G+B+C(\bar{R})-Z\right) .
$$

Assume that operatives are considering a target of difficulty $D$, and have a willing suicide attacker. They then choose between the maximum of expected utility in expressions (7a), (7b) and (7c). The utility of a loyal operative from a suicide attack (7c) is illustrated by the serrated line in Fig. 3. The operative's utility is relatively low for the suicide tactic at low damage because of the loss of the attacker $(-Z)$. Expected utility increases more quickly in damage for the suicide than for the conventional attack because the probability of apprehension affects only the conventional attack. Consider the hard target (high $p$ ). The high probability of apprehension, $p$, is relevant for a conventional attack but does not affect the utility of a suicide attack. For targets with damage greater than $D_{\mathrm{D}}$ suicide attacks dominate conventional attacks as long as they are incentive-compatible, i.e., $7 \mathrm{c}>7 \mathrm{a}$ and $7 \mathrm{c}>7 \mathrm{~b}$ on the interval $\left(D_{\mathrm{D}}, D_{\mathrm{E}}\right)$. To the left of $D_{\mathrm{D}}$, and at lower apprehension probabilities, the reduction in apprehension risk does not compensate for the high cost to the club of losing a cadre, so suicide attacks are not used. ${ }^{35}$

The figure illustrates a second testable implication of our analysis, as targets harden conventional attacks are disfavored (the solid curve representing the utility of a loyal operative in a conventional attack shifts downward), and suicide attacks are increasingly chosen. For instance as defensive expenditures harden targets, expected utility from conventional attacks falls, so the interval $\left(D_{\mathrm{D}}\right.$, $D_{\mathrm{E}}$ ) of feasible suicide attack targets widens, implying less conventional and more suicide attacks. In terms of the insurgency literature and Table 2, while weak government and difficult topography predict the use of conventional insurgent tactics, they will not predict the use of suicide attacks, which, given their cost, are chosen when conventional insurgency fails.

\footnotetext{
35 Extending the discussion of rational martyrs above we could incorporate the decision of the suicide attacker, with utility from defecting (7b) $U\left(D+w_{i}, 0, G\right)$, and utility from remaining loyal $\left(7 c^{\prime}\right) U\left(\frac{\alpha^{\prime} D}{N}, 1,-Z^{\prime}\right)+U^{H}$, where $\alpha^{\prime}>\alpha$ (the attacker gets a larger share of the glory), $Z^{\prime}>Z$ (the attacker cares more than the operatives about his own demise) and $U^{H}$ represents either the value of rewards in the afterlife or the value an altruist gets from the benefit his action is expected to have for his friends and family. The critical point is that rational operatives will choose a suicide attacker so that 7c'>7b for values of $D$ for which $7 \mathrm{c}>7 \mathrm{~b}$ (i.e., other operatives will not defect). If $\alpha^{\prime}$ or $U^{H}$ are large enough, or $Z-Z$ small enough, the attacker need not be a club member (with low outside options $w$ ), which is often the case and has the advantage of limiting exposure of operatives if the suicide attacker is caught. Following Merari's work, the key assumption is that suicide attackers with appropriate values of $\alpha^{\prime}, U^{H}$ and $Z$ are available.
} 


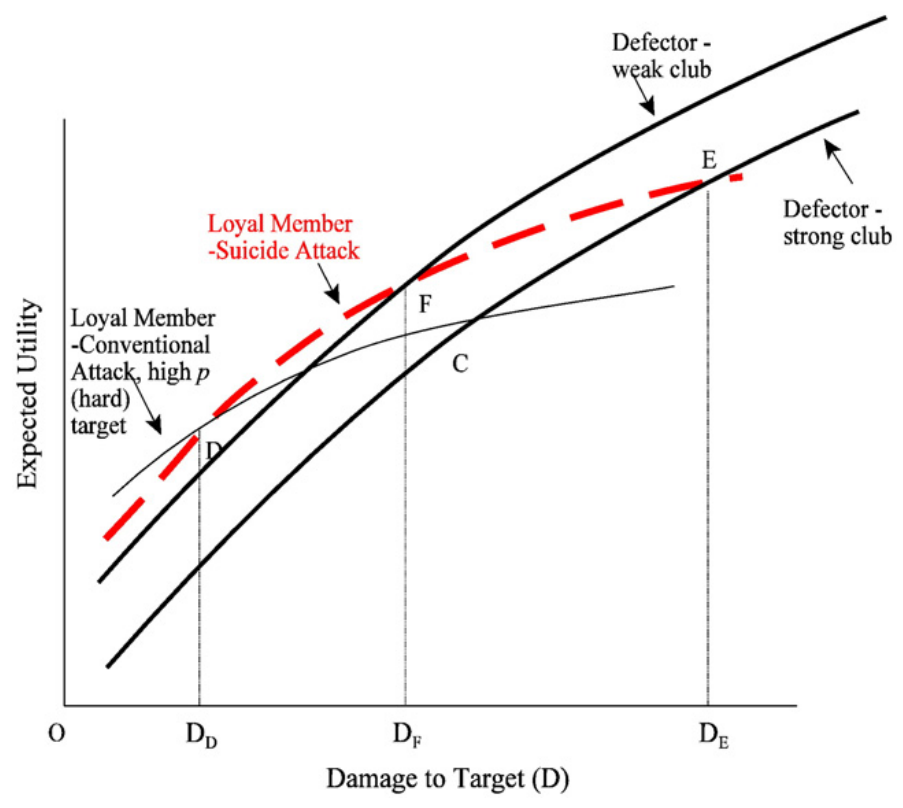

Fig. 4. Strong clubs choose deadlier suicide attacks.

The figure also clearly illustrates the argument made informally above to explain why suicide attacks are the tactic of choice for targets of different religions, as we saw in Table 3. Religious difference hardens targets by enabling profiling and raising the probability of capture, making suicide attacks the optimal tactic (i.e., lowering the loyal operative's expected utility curve for conventional attacks in Fig. 3). In contrast, coreligionists are soft targets, allowing them to be "successfully" attacked without incurring the cost of a lost cadre.

\subsection{Strong clubs and suicide attacks}

What type of rebel organizations can thrive in a hard-target environment? Here the club model of radical religious groups yields a third testable implication: The stronger the social-service provision of a club the more damaging the suicide attacks it takes on.

This result comes from the interaction of club strength, choice of tactics and damage. Clubs with the ability to screen operatives likely to defect will have an advantage in such conspiracies. Consider heterogeneity in outside options, $w$, as above. Assume parameters are such that operatives with good outside options will defect while those with poor outside options can organize a suicide attack $\left(D>D_{\mathrm{F}}\right)$. I.e., there is some cutoff wage $w^{\prime}$ for which operatives are indifferent at $D_{\mathrm{F}}$ and $w^{L}<w^{\prime}<w^{H}$. A club with the capacity to extract signals of commitment (low wages) can successfully exclude potential defectors - those high wage applicants who have not demonstrated organizational commitment. ${ }^{36}$ The more selective club with $w=w^{L}$ members can successfully implement a more damaging suicide attack (in the interval $D_{\mathrm{E}} D_{\mathrm{F}}$ ) than a weak club with $w=w^{H}$ (which cannot exceed damage $D_{\mathrm{F}}$ ).

Fig. 4 also illustrates why suicide attacks are rare. The utility of a defector from a weak club is shown by the upper bold line. His utility from defection is high because he has strong outside options, $w$, (or perhaps because he is not community-minded or would suffer minimally from his extended family being ostracized). His propensity to defect makes him a poor operative, allowing incentive-compatible suicide attacks only in the small range $D_{\mathrm{D}}<D<D_{\mathrm{F}}$. The suicide attack is only worth doing if it will create high damage and high damage implies high temptation to defect.

In contrast, a strong club has selected operatives with a lower utility from defection (and perhaps taken care to limit their outside options by having them choose seminaries and incarceration over school and work), as illustrated by the lower bold line. A strong club has lower utility from defection for a given level of damage since members are selected to have worse outside options, as represented by the rightmost curve. Those operatives will choose loyalty over defection up to damage level $D_{\mathrm{E}}$. That advantage is expressed as an expansion in its capability to carry out suicide attacks, with no effect on the decision to carry out conventional attacks. The strong club will use a wider range of targets for suicide attacks $\left(D_{\mathrm{D}}, D_{\mathrm{E}}\right)$, while the weak club will attack targets only in smaller damage range $\left(D_{\mathrm{D}}, D_{\mathrm{F}}\right)$. Since operatives' utility increases in damage, given that they have a willing suicide attacker recruited, they will attack targets with the maximum damage which is incentive-compatible ( $D_{\mathrm{F}}$ for the weak club, $D_{\mathrm{E}}$ for the strong club). Thus, if the environment favors suicide attacks for both weak and strong clubs, the suicide attacks carried out by the strong club will be deadlier.

A fourth implication is also illustrated by Fig. 4. The stronger the social-service provision of the club, the greater the proportion of its attacks will be suicide attacks. ${ }^{37}$ Both strong and weak clubs will carry out low damage conventional attacks in the interval where the value of the target does not justify losing a suicide attacker. Since the strong club has a larger range of incentive-compatible

\footnotetext{
${ }^{36}$ Examination of Eqs. (7a, 7b, 7c) reveals why clubs put operatives with strong outside options (i.e., high $w$ ) under special scrutiny - they are more likely to defect. To be trusted, high wage operatives would need to compensate by making credible claims to organizational loyalty (e.g., that agents of the state murdered the claimant's brother or raped his/her sister). High-wage recruits who can signal loyalty will prefer to volunteer in low-wage high-sacrifice organizations for the same reason that any operative would - to protect themselves from defection by comrades.

37 This implication is true in the "single crossing" case illustrated in the figure. A weaker sufficient condition is that consumption and public goods are not such extremely strong complements that conventional attacks dominate both suicide attacks and defection for some high damage project $D>D_{\mathrm{E}}$.
} 
suicide attack targets than does the weak club, we expect to see a greater proportion of suicide attacks by the strong club (since weak clubs may sometimes have no feasible suicide attack options.) We now turn to testing these four implications of the analysis.

\section{Testing: clubs, hard targets and suicide terrorism}

The club framework developed in the last section was designed to explain the effectiveness of religious radicals as rebels and their use of suicide terrorism. Starting with effectiveness, the model had a clear testable implication: religious radicals can confidently take on high-value targets if they are affiliated with a club that provides local public goods. Recalling the discussion of Figs. 2 and 3, clubs have two advantages, both of which reduce defection: first, they recruit members who signal commitment or poor outside options through sacrifice; second, the services they provide to members (and their families) provide extra motivation not to defect.

That implication can be tested using data on the lethality of terrorist attacks in Israel and Lebanon. Our grisly measure of effectiveness is the lethality of the attack, which we take as an indicator of the project value, assuming that the willingness of governments to bribe operatives into defection increases in the number of lives at stake. Table 4 reports on international terrorist attacks by organization for the period spanning January 1968 through December 2006.

Our data source is the Terrorism Knowledge Base (www.tkb.org) compiled by the Memorial Institute for the Prevention of Terrorism, which collects international terrorist incidents dating back to January 1998, recording location, attacker, tactic, injuries and fatalities. The incidents data integrate international incidents previously collected by the RAND corporation dating back to 1968. The table reports on incidents spanning the period from January 1968 through December 2006. We included all organizations currently active with at least 10 attacks recorded.

We used the description of these groups in the ICT dataset (whose coders did not have our theory in mind) to see if there was any mention of social-service provision by each organization, as an indicator of being a "strong club." That classification yielded two social service providing organizations, Hamas and Hezbollah. Table 4 lists organizations in order of lethality. Social-service providers Hamas and Hezbollah are responsible for the most lethal attacks. Hamas carried out 70 attacks, killing 413 people and injuring 2202. Hezbollah is responsible for 90 attacks, 449 deaths and 387 injuries. Measuring fatalities per attack, Hamas averaged 5.9 while Hezbollah averaged 5.0. The remaining terrorist organizations on the list, none of which are social-service providers, are far less lethal: the Palestinian Islamic Jihad averages 2.9 fatalities per attack, the Popular Front for the Liberation of Palestine 2.8 fatalities, Fatah/PLO averages 2.7 fatalities per attack, and the Democratic Front for the Liberations of Palestine average 1.0. In attacks where the affiliation is unknown, the average is 0.8 . Note the relatively low lethality of the Palestinian Islamic Jihad. It is a Sunni radical Islamic organization which shares the same theology as Hamas but has no social-service provision network, and is about half as lethal in its operations.

The bottom two rows of Table 4 report the aggregate contrast between the lethality of the two clubs, who provide social services, and all the other terrorist organizations, which do not. Hamas and Hezbollah averaged 5.4 fatalities over 160 attacks, killing 862 people. The other organizations averaged 2.3 fatalities per attack over 228 attacks totaling 519 deaths. The difference is significant $(p=0.06)$. (If the standard error is clustered by group $p=0.002$.) Social-service providers are more lethal than other terrorists - including other religious terrorists, as predicted by the club model.

\subsection{Hard targets and suicide attacks}

Turning now to the choice of terrorist tactics, the discussion of hard targets yielded a testable implication: Suicide attacks are reserved for targets that are well enough defended that their destruction is unlikely using conventional tactics.

That conjecture can be tested on data available from Israel and Palestine. Palestinian insurgents in the West Bank and Gaza have an extensive choice of soft targets. Israeli settlers and soldiers use roads that pass through heavily populated areas or

Table 4

Social-service provision and lethality of terrorist attacks Israel and Lebanon: 1968-2006

\begin{tabular}{|c|c|c|c|c|c|c|}
\hline Group name & Attacks & Injuries & Fatalities & Injuries/attack & Fatalities per attack & (SE) \\
\hline Hamas & 70 & 2202 & 413 & 30.2 & 5.9 & 0.87 \\
\hline Hezbollah & 90 & 387 & 449 & 4.3 & 5.0 & 2.82 \\
\hline Palestinian Islamic Jihad & 38 & 722 & 111 & 12.7 & 2.9 & 0.81 \\
\hline Popular Front for the Liberation of Palestine & 38 & 376 & 107 & 9.9 & 2.8 & 1.03 \\
\hline Fatah/PLO & 131 & 1465 & 279 & 11.20 & 2.1 & 0.48 \\
\hline Democratic Front for the Liberation of Palestine & 21 & 240 & 22 & 10.4 & 1.0 & 0.37 \\
\hline Unknown & 427 & 1055 & 351 & 2.2 & 0.8 & 0.28 \\
\hline Social-Service Providers: Hamas and Hezbollah & 160 & 2589 & 862 & 15.8 & 5.4 & 1.62 \\
\hline Others: DFLP, Fatah/PLO, PIJ, PFLP & 228 & 2632 & 519 & 11.6 & 2.3 & 0.35 \\
\hline Difference & & & & & 3.1 & $1.67^{\mathrm{a}}$ \\
\hline
\end{tabular}

Source: Memorial Institute for the Prevention of Terrorism database (tkb.org), as of 5/17/07. Listed are groups currently active with at least 10 attacks.

Notes: International attacks include attacks abroad, domestic targets associated with a foreign state or airline attacks designed to create an international incident. Terrorism is "violence or the threat of violence, calculated to create an atmosphere of fear or alarm... generally directed against civilian targets." For details see www.tkb.org/RandSummary.jsp?page=about.

a This reported standard error is heteroskedasticity-robust. The estimated standard error allowing for clusters of correlated fatalities within organizations is smaller, at 0.66. 
Table 5

Attacks on Israeli residents by location and tactic Sept 2000 through July 2003

\begin{tabular}{|c|c|c|c|c|c|}
\hline Location & Attacks & Fatalities & (Of which) Suicide attack fatalities & Fatalities/attack & Suicide attack fatalities/attack \\
\hline$\overline{\text { West Bank and Gaza }}$ & 17405 & 341 & 8 & 0.020 & 0.00046 \\
\hline Inside Green Line & 730 & 511 & 401 & 0.700 & 0.54932 \\
\hline $\begin{array}{l}\text { Difference } \\
\text { (std. error) }\end{array}$ & 16675 & -170 & -393 & $\begin{array}{l}-\mathbf{0 . 6 8 0} \\
(0.017)\end{array}$ & $\begin{array}{l}-0.54886 \\
(0.05460)\end{array}$ \\
\hline
\end{tabular}

Note: Standard errors are calculated by treating the expected number of fatalities per attack as a probability and assuming that attacks are independent.

Sources: Attacks, fatalities and fatalities due to suicide attacks inside the "green line" are from the Israel Defense Forces spokesperson's office, as reported by Nadav Shragai in Ha'Aretz, September 26, 2003. Fatalities in West Bank and Gaza due to suicide attacks are from the ICT data as described in the Appendix to Berman and Laitin (2008)

through terrain that make them vulnerable to ambush. Settlements and military locations are also quite exposed and often in proximity to large Palestinian populations. As a result an attacker can fire a weapon or detonate a bomb remotely, flee relatively easily, and blend into the local population. In contrast, targets on the Israeli side of the "green" line are much "harder," posing much greater risks for the attacker. To reach the target the attacker must negotiate checkpoints and perhaps a security fence where his weapon could be discovered. Once on the Israeli side, security forces and civilians can profile the attacker by "reading" his ethnic markers. After an attack, the attacker would face a heightened version of all those risks on the way back to some safe location in Palestine.

Applying our conjecture to the Israeli case, we predict that attacks within the green line are more likely to use suicide tactics. Table 5 reports data on attacks and fatalities by location and method for the period from the beginning of the second Intifada (September 2000) through July 2003. Attacks include all forms of violence toward Israelis and residents of Israel as recorded by the IDF, aggregating suicide attacks with shootings, roadside bombs, stone throwing and other tactics. The vast majority of recorded attacks are against soft targets in the West Bank and Gaza (96\%). The next column records fatalities due to attacks, which indicates that the majority of fatalities (60\%) are on the Israeli side of the green line. While there is no direct information about choice of methods, the methods used on the Israeli side of the green line are clearly deadlier.

Conditional on fatalities, we can compare method by location. Suicide attacks killed eight people in the West Bank and Gaza while killing 401 on the Israeli side of the green line. That is to say, 17,405 attacks in the West Bank and Gaza resulted in eight deaths due to suicide attacks while 730 attacks in Israeli proper caused 401 deaths due to suicide attacks. The data show that suicide attacks are disproportionately used against the relatively "hard" targets on the Israeli side.

We interpret this evidence of tactic choice as supporting the usefulness of the hard/soft target distinction, reinforcing our conjectures about Tables 2 and 3. Hard targets provide a clear explanation for why suicide terrorism is not the tactic of choice for a typical insurgent operating in a poor hilly country against people who look like him: insurgents have lethal options that do not require the certain death of loyal cadres, typically attacking coreligionists who cannot easily profile attackers. Rebel leaders facing harder targets are more likely to choose suicide attacks. High-income countries, their allies, and members of other religions provide hard targets.

\subsection{Strong clubs vs. hard targets}

Combining the logic of clubs with that of hard targets yielded two further implications in the analysis of the last section. First, as Fig. 4 illustrated, among groups attempting suicide attacks, strong clubs can take on more lethal attacks without risk of defection. Second, the analysis suggests that strong clubs will choose suicide attacks as a greater proportion of their attacks.

The combined dataset reports on suicide attacks between 1981 and 2003 in Lebanon and Israel/Palestine. Table 6 reports on organizations which have carried out suicide attacks. They were selected according to the criterion of having carried out at least one suicide attack. Fig. 4 indicates that this is the range of organizations for which the model can make predictions. We again used the description of these groups in the ICT dataset as social-service providers as an indicator of being a "strong club," yielding two social-service providing organizations, Hamas and Hezbollah. Recall that both these organizations provide a large variety of excludable services to communities, including education, health care, welfare services and even law and order. ${ }^{38}$ During the sample period Hamas and Hezbollah carried out 63 and 44 suicide attacks respectively. The Palestinian Islamic Jihad carried out 37 attacks. Four non-Islamist organizations carried out suicide attacks in this period: The Martyrs of Al Aqsa (which is allied with Fatah), the Popular Front for the Liberation of Palestine (PFLP), the Fatah - the political party that dominates the PLO, and the Syrian Social Nationalist Party (SSNP).

As our model predicts, the two social-service providing organizations are much more efficient (i.e., lethal) in their attacks. Hamas average 7.2 fatalities per attack, while the Hezbollah average 17.3. The PIJ, Islamists who lack a social-service provision capacity, average 4.0 fatalities per attack. The four secular organizations are all less lethal than that; the most important being the Fatah-affiliated Al Aqsa Martyrs who average 2.8. Taken together, the two organizations with social-service provision networks carry out more attacks and are more lethal, averaging 11.4 fatalities per attack, as opposed to the five organizations without a social-service provision network, which average 3.3 fatalities per attack. The difference in fatalities associated with social-service

\footnotetext{
38 Whether Hamas and Hezbollah actually exclude individuals who are not committed from receiving services is hard to document. Both have strong incentives to present them selves as nondiscriminatory, both to potential voters and to donors. Flanigan (2008) argues that Hezbollah provides services preferentially to families of fighters.
} 
Table 6

Social-service provision and lethality of suicide attacks Israel and Lebanon

\begin{tabular}{llll}
\hline Organization & Social services ${ }^{a}$ & Suicide attacks & Average fatalities/attack \\
\hline Hamas & Yes & 63 & $7.2(0.9)$ \\
Hezbollah & Yes & 44 & $17.3(5.9)$ \\
\hline Palestinian Islamic Jihad & No & $37.4(4.9)$ & $4.0(1.0)$ \\
Popular Front for Liberation of Palestine (PFLP) & No & 7 & $2.9(1.0)$ \\
Martyrs of al-Aqsa & No & 31 & $2.8(0.8)$ \\
Fatah & No & 2 & $0.5(0.5)$ \\
SSNP & No & 1 & $0(-)$ \\
\hline Difference & & & $3.3(0.4)$ \\
\hline
\end{tabular}

Notes: Suicide attack data is described in the Appendix to Berman and Laitin (2008).

a In its review of organizations, ICT mentions the provision of social welfare benefits to ordinary citizens, going beyond ideological, religious and military tasks.

b Std. errors (in parentheses) allow for clusters of correlated fatalities within organizations.

Table 7

Social-service provision and tactic choice-Palestinian organizations

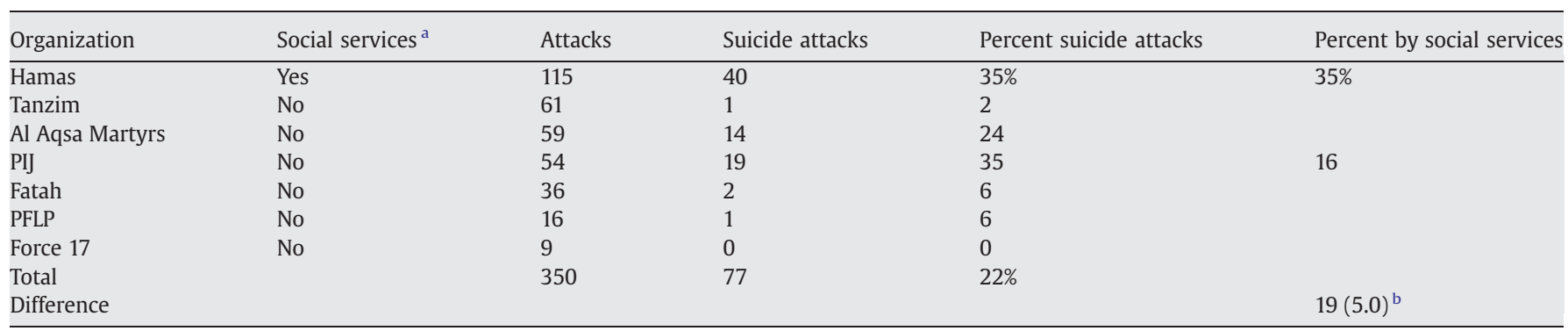

Notes: Data from ICT dataset (http://www.ict.org.il/) covering the period January 1980 through December 2002 (downloaded 12/06). Figures are not comparable to those in Table 6 as they cover a different period and they classify Fatah into more suborganizations (Tanzim, Al Aqsa Martyrs, Force 17, Fatah). Hezbollah omitted because the ICT dataset reports far fewer Hezbollah attacks in Lebanon than does the combined ICT/Pape dataset.

${ }^{a}$ In its review of terrorist organizations, the ICT mentions provision of social welfare benefits to ordinary citizens, going beyond ideological, religious and military tasks.

b Standard error calculated assuming independent attacks.

provision, 8.1, is statistically significant. ${ }^{39}$ This finding is consistent with the case of the Jewish Underground of the 1980 s, a Jewish religious terrorist organization. Like the PIJ, it had a murderous theological motivation, but provided few social services, was a very weak club, and was easily infiltrated and shut down by Israeli intelligence (Berman, 2003).

An alternative explanation for the high lethality of Hamas and Hezbollah is that they are simply larger organizations, providing greater recruiting and logistical capabilities. Yet if size were a dominant factor in terrorist lethality, Fatah would dominate Hamas, the early Hezbollah would have been less lethal than the competing Lebanese militias, the former Mujaheddin would have been more effective at coordinated violence than the Taliban in the mid 1990s, and the neo-Baathists would be more lethal per attack than Iraqi AlQaeda.

The club model has an additional implication, that strong clubs will choose the suicide attack tactic more often. Recalling the discussion of Fig. 4, strong clubs attack targets in the interval $D_{\mathrm{F}}$ through $D_{\mathrm{E}}$ for which only the suicide tactic is effective, while weak clubs cannot.

Table 7 reports all attacks by Palestinian organizations, including both conventional and suicide attacks. These data come directly from the ICT website and cover the years 1980-2002. The ICT distinguishes within the Fatah between Force 17, Tanzim and Fatah, making a total of seven groups. Hamas and the Palestinian Islamic Jihad have the highest proportion of suicide attacks among attacks, with 35\% each. The Al Aqsa Martyrs follow with $24 \%$. All other groups have $6 \%$ or less. With the exception of the PIJ, the pattern is as predicted by the model. Hamas, the strong club, chooses the suicide attack tactic at least as often as does PIJ, which has very little if any social-service provision, and more than Fatah and PFLP. The difference between the proportion of suicide attacks carried out by Hamas and the organizations with no social-service provision capacity is nineteen percentage points and is statistically significant. ${ }^{40}$ We read these results as broadly consistent with the model's prediction that strong clubs will exploit their organizational advantage in suicide attacks.

\subsection{Iraq, Sri Lanka and Chechnya}

Does our analysis apply beyond Israel/Palestine and Lebanon, where we have high quality data? We examine Iraq, Sri Lanka and Chechnya - where suicide attacks have been used. New data compiled by Gambetta (2006, p. 309) on suicide attacks in Iraq (May

\footnotetext{
39 The careful reader will notice discrepancies between reported suicide attacks based on a number of data sources and all attacks reported in Table 4 . The TKB incidents have a longer sampling period but include only "international" attacks. We have not attempted to reconcile the two sources for individual attacks.

40 The fact that the PIJ chooses suicide attacks so often despite its lack of social service provision may indicate that theology and indoctrination motivate suicide attackers. Alternatively, the PIJ might incur a smaller loss, $Z$, from the demise of a cadre because, lacking political aspirations, they have less need to explain the loss to family and community and less eventual use for committed members.
} 
2003 through January 2006) provide a further test. Gambetta distinguishes three groups of attackers: the Sunni groups of former Baathists; Al-Qaeda in Iraq; and Ansar al Sunna. The latter two are religious radicals: Al-Qaeda, and Ansar al Sunna from Kurdistan. Of the 160 suicide attacks for which a target can be classified, $81 \%$ are aimed at coalition forces and are thus inter-religious. This figure is in line with the international data, in which about $87 \%$ of suicide attacks were inter-religious (Table 3 ). Suicide attacks are generally directed against Coalition forces or well-defended Iraqi targets. Softer targets such as oil pipelines, which are extremely difficult to protect, do not merit suicide attacks. This is consistent with the prediction of the model and the findings in Table 5 for Israel/Palestine; suicide attacks are reserved for hard targets.

More importantly, Gambetta finds that of the 152 suicide attacks for which he can name a perpetrator, the two groups of religious radical terrorists are much deadlier, with Al-Qaeda averaging 39 deaths per attack (41 attacks), Ansar al Sunna averaging 28 deaths per attack ( 8 attacks), and the Sunni Groups averaging a much smaller 10 deaths per attack (103 attacks). This pattern is consistent with the prediction of our model that, compared to the Bathists, religious radicals can permit themselves to carry out much larger attacks without violating a defection constraint (as illustrated in Fig. 4) because their members are selected to have higher levels of commitment, as we found in Israel/Palestine and Lebanon. An important caveat to that conclusion is that we know little about social-service provision by the groups from which Al-Qaeda Iraq recruits. That is a topic for further research.

In Sri Lanka, the LTTEs Black Tiger's use of suicide attacks highlights how specific our model is to asymmetric warfare. The Sri Lankan government is not strong enough to control the territory from which the LTTE operates, so that capture of an attacker does not trigger assassination or capture of operatives, as would likely be the case in Israel or Iraq. The Sri Lankan environment favors standard insurgency, which for the most part is what has occurred since 1984. That insurgency is not carried out by an organization which fits the club model: the LTTE is not religious, does not provide social services exclusively to members and does not send valuable members on suicide attacks (Bloom, 2005).

Even so, our analysis provides some insight. Suicide attacks are reserved for targets for which conventional attack is unlikely to succeed. In the early years of the Tamil insurgency, as Swamy (1994) reports, most attacks were intra-Tamil, as many groups vied to become the monopoly representative of the Tamil population. In this intra-Tamil killing there were no suicide attacks. Nor were there suicide attacks in the internal war among Tamil Tigers in 2005 over negotiation strategy with the government. As Hopgood (2006, 72) points out, when Sri Lanka launched Operation Liberation in mid-1987, establishing military camps in the heart of the LTTE-controlled zones, the Black Tigers were formed to use suicide attackers to attack these targets, for lack of alternative weapons (Hopgood, 2006, 75). The LTTE has also recognized the problem of defection. Gambetta (2006) points out that the Black Tigers "are subject to a commitment pressure by having a ritual dinner with their leader, Pirabakaran, before the attacks - a subsequent defection would imply a catastrophic loss of faith." This suggests that our focus on the problem of defection is not particular to the Middle Eastern cases or to radical Islamists.

Similar anomalies appear in the case of the two Chechen wars (1994-1996; 1999-) in Russia. In the first, the so-called boyeviki (insurgents), according to Lieven "lack a military hierarchy and organization, formal training, formal commanders and tactical doctrine..." Lieven also notes numerous reports in the first war where "death squads shoot people [other Chechens] on the square, kill members of parliament inside the parliament building, and, finally shoot a dozen disloyal policemen at the city's police headquarters - the killing of Chechens by Chechens.....In front of video cameras, Shamil Basayev executed an old man who had been a local administrator in his native village..." This was hardly a war organized by a coherent organization seeking to maximize effect by going after spectacular hard targets (Tishkov, 2004, quoting Lieven).

Yet our model captures key strategic elements in the Chechen insurgency. First, the primary targets for Chechen suicide attacks are Russian civilian and military complexes, which are hard targets. The largely Eastern Orthodox Russian police and military profile Muslims from the Caucasus and keep them under strict surveillance. Conversely, soft targets (for example, the so-called Chechen traitors, who are not well protected by the Russian army) do not merit suicide attacks. Second, Chechen suicide attacks did not begin until after Wahhabi fundamentalists, funded by the bin Laden network, began operating in Chechnya. They provided locals with needed social services. There was, for example, a $\$ 1000$ reward for new converts, and families of converts got stipends of $\$ 100$ per month during the war. In exchange, the Wahhabi demanded prohibitions and sacrifices. Women were forced out of the job market. The new religious leaders demanded "compulsory prayers, Arab clothes, a ban on shaving, banishment of the ustazes [Sufi shaykhs]," and clean breaks from family (Tishkov, 2004, 172-6). These Wahhabis, Tishkov shows, have been the source of the suicide strategy. In sum, suicide attacks in the Chechen rebellion were initiated by religious radicals providing benign services, and are associated with hard targets.

To summarize, the club model of terrorism, augmented with an analysis of tactic choice when targets are hardened, was designed to explain the lethality of radical religious rebels and the choice of suicide attacks by rebels. Its testable implications are supported when confronted with data on attacks in Israel, Palestine and Lebanon: social-service providing clubs are more lethal, particularly at suicide attacks; suicide attacks are chosen against harder targets; and social-service providing clubs tend to specialize in suicide attacks. These findings are not refuted by qualitative evidence on the use of suicide attacks in Iraq, Chechnya and Sri Lanka. We turn now to the implications of that analysis for policies to defend hard targets against terrorist clubs.

\section{Implications for counter-terrorism policy}

The club model implies that religious radicals will be active when government provision of public goods is weak and when nonmilitia market opportunities are poor. While a comprehensive study of other cases is beyond the scope of this paper, that seems to describe Somalia, Nigeria, Algeria, Afghanistan, Kashmir, Tajikistan, Yemen, Bosnia and the Philippines. Radical religious rebels have especially thrived during periods of weak social-service provision by government in Lebanon, Afghanistan and Egypt. Collapse of Soviet authority was accompanied by an increase in radical Islamic militia activity throughout Central Asia, just as the 
collapse of Tsarist Russia was, seven decades earlier (Rashid, 2002). Saudi Arabia is an exception: a country with fairly generous provision of local public goods for a developing country but with radical religious militias nonetheless. ${ }^{41}$ Al-Qaeda, though not a club providing social services, has recruited successfully in all these areas among radical Islamists. Berman (in press) discusses nonreligious clubs.

Sadr's militia in Iraq fits the model. As basic government service provision broke down during the period of sanctions in the 1990s, radical Islamic groups stepped in to fill the void (Dodge, 2004). This was especially true for Shia, who were the first to lose services from the Sunni dominated government. One of these radical Islamic social-service providers was organized by the father of Muqtada al Sadr, and inherited by Sadr after his father's assassination. The younger Sadr used this organization to control the Al Tharwa slums of Baghdad ('Sadr City') in the chaos following the American occupation, by quickly providing basic services, such as law and order, food and medicine. Not unlike the Taliban, Sadr's organization grew quickly from a small band of clerics providing social services to a potent militia, using violence and intimidation coupled with access to social services to gain considerable power. These gains have come at the expense of the established Shia clergy, the Ulema, led by Ayatollah Sistani, who have more impressive theological credentials but lagged behind in service provision.

The club model also implies that subsidies to militias can dramatically increase not only militia activity but also the intensity of prohibitions (Berman, 2000). That has been true in Afghanistan since the early 1980s, when massive Saudi and Western subsidies to the Mujaheddin apparently turned a relatively secular population into radical Islamists, long before the organization of the Taliban. Similarly, subsidies from Iran have exacerbated radical religious practice and militia activity by Hezbollah in South Lebanon.

This economic model of radical Islamic militias has clear policy implications for counter-terrorism that flow directly from the analysis of incentive compatibility conditions (5) and (6) and the discussion of Figs. 2, 3 and 4. Interventions that weaken incentive compatibility will lower $B^{*}$, the maximal project value a militia can undertake. Thus, a government which seeks to reduce militia activity and increase attrition from militias could: 1 ) block transfers to clubs operating militias i.e., lower $C ; 2$ ) improve alternative provision of local public goods accessible to both members and nonmembers, i.e., raise $G ; 3$ ) reduce smuggling rents and other rents that clubs operating militias can aspire to capture, i.e., limit access to $B ; 4$ ) improve outside options, i.e., raise $w$.

Fig. 2 illustrates the effects of transfers to clubs. A subsidy that augments $C$ or that provides cash payments to members can induce a discrete increase in militia activity for project values in the $\left(B^{*}, B^{* *}\right)$ range. This may explain why even relatively small cash payments to families of suicide bombers, or small increases in the prestige that the community rewards those families with, ${ }^{42}$ can induce large increases in coordinated militia activity.

This is nonstandard development economics. In considering the effect of aid on failed states, it is worth stressing the contrast between subsidizing club goods and subsidies to government-provided public goods. While both increase the flow of public goods to the local population, subsidies to clubs can create an incentive to increase militia activity. The critical difference is that government provision of public goods is nondiscriminatory, in the sense that it is not conditional on some norm of behavior that a club requires of members. ${ }^{43}$ For that reason raising $C$ increases militia activity, as it increases the leverage clubs have with members, while raising $G$ reduces the influence of clubs by making members less dependent on club services, thus reducing the damage a militia can do. Therefore outside support for embattled governments will reduce militia activity if those governments use it to augment basic service provision in a nondiscriminatory manner. Nondiscriminatory provision of services by NGOs would serve the same function.

Another course of action for governments who want to weaken club-militias is to reduce economic rents, $B$, available to be captured. In the Afghan case many of these rents are due to the drug trade and the returns to smuggling caused by high duties and tariffs. For example, any reduction in demand for heroin in Europe, the primary destination of Afghani opium, would reduce rents available for Afghan militias to capture. As another example, a particularly distorting institution was the Pakistani-Afghan agreement on goods imported in bond. Goods bound for Afghanistan could be imported into the Pakistani port of Karachi free of Pakistani duties and tariffs. They were then trucked legally into Afghanistan and almost inevitably smuggled back into Pakistan, creating huge rents for Afghan smugglers and militias (Rashid, 2000).

Recent Egyptian history provides an instructive example in weakening militias. Though Gamal Abdel Nasser rose to power by creating a partnership with the MB, the alliance was short-lived. Feeling threatened, Nasser not only imprisoned the leadership but nationalized the MB's well developed social-service provision network (Munson, 2002). The subsequent two-decade decline in MB activity, both violent and benign, is consistent with models' prediction that provision of benign local public goods is an essential part of the organization.

Farther afield, limiting the ability of a club to provide benign local public goods, such as mutual insurance, was apparently part of a successful British policy to combat insurgency during the colonial period. For example, the communist insurgency in Malaya was apparently controlled by aggressively enforcing a British monopoly on both violent and benign local public good provision. The British managed to stabilize the military control of their allies and eventually transfer power to those allies and leave peacefully (Thompson, 1966).

The single most important tool in weakening militias may be inducing defection by improving members' outside options. Fatah provides an example. Their Black September cell became a potential liability to the parent organization in the early 70 s. It was successfully retired by providing members with steady jobs, apartments and even brides in Beirut (Hoffman, 2001).

\footnotetext{
41 Saudi Arabia is an exception but perhaps not a puzzle. Its relatively generous welfare system must cope with extraordinarily large cohorts o f young unemployed workers due to a combination of high rates of demographic increase and stagnant labor markets (Fandy, 1999), especially in the poorest regions, from which the terrorists tend to come. We thank an anonymous referee for pointing this out.

42 Prestige could have the very concrete interpretation of preferred access to local public goods.

43 That is literally true only in the model. Governments often do exclude access to public goods as a means of law enforcement, but have less distortionary sanctions at their disposal as well, such as taxes and an impartial judiciary.
} 
Strengthening outside options is a mechanism through which economic development can weaken militias, as appears to have happened in Northern Ireland. It is important to point out that economic development may be effective in weakening militias even if activists within a militia are not disproportionately poor, and support for militia activities is not disproportionately among the poor, findings reported by Krueger and Maleckova (2003). A club which is strengthened by its ability to provide local public goods may attract members for any number of reasons, and select leaders and combatants from among those members according to characteristics other than poverty. In any case, the club good model focuses not on the popularity of the militia but on its effectiveness. The most effective militias do seem to require large infrastructures and a committed membership, which do seem to be disproportionately located in places with poor market opportunities and poor government provision of local public goods (i.e., Afghanistan, Palestine, Lebanon, Sudan, Algeria, Chechnya, Pakistan, Yemen, Bosnia, Kashmir and more recently Iraq).

\subsection{Countering suicide attacks}

These counter-terrorism policies apply particularly to suicide attacks. Notice that in a hard-target environment once suicide attacks are being used, further hardening of targets affords little extra protection. Fig. 4 illustrates the feasible range of attacks possible for a strong club, with the highest damage attack at $D_{\mathrm{E}}$. Consider the effect of further investments in raising the probability of catching an attacker (raising $p$ or "hardening" a target). That would reduce the utility of a loyal operative, shifting the intersection point $D_{\mathrm{D}}$ to a lower level of damage. That removes some low value targets to the left of $D_{\mathrm{D}}$ from the risk of conventional attack, but exposes them to the risk of suicide attack. Since suicide attacks will tend to be concentrated at the high damage end of their feasible range (operatives are utility-maximizing), that investment in raising $p$ is wasted. To make matters worse, defensive expenditures on hardening targets, such as airport security, guards in front of shopping centers and restaurants, or increased monitoring of borders may only shift risk between targets rather than reduce overall risk (Trajtenberg, 2006). Simply put, raising the probability of capture is of little use once the club has chosen the suicide attack tactic.

Protecting high-value targets against suicide attacks by strong clubs requires an altogether different approach. A more productive strategy would be to increase pressure to defect by competing with clubs. At higher defection probabilities, high-value targets become infeasible (incentive incompatible) for operatives - organizations will not attempt to attack them for fear of being compromised. Referring again to Fig. 4, imagine enhancing the return to defection for operatives in a strong club. That shifts upward the lower bold curve representing the utility from defection for a member of a strong club, which shifts the point of intersection $E$ to the left, making the highest value targets infeasible (around $D_{\mathrm{E}}$ ). That protection of high-value targets can be achieved by improving options for operatives outside the club, a policy that the model predicts will work especially well against high-value targets at risk of suicide attacks.

Another method of protecting high-value targets is by weakening club provision of services (shifting the utility curve of loyal members downward). In Fig. 4 that counter-terrorism tactic would be illustrated by shifting the dashed line representing the utility of loyal members from a suicide attack downward to lower levels of utility. That shifts the intersection point $E$ to the left, protecting the highest value targets (around $D_{\mathrm{E}}$ ) by making them infeasible for the club to attack. Improving competing services provided by local government and markets will have a similar effect. Both these policy implications are consistent with the emphasis U.S. commanders in Iraq have requested on job creation and spending on local public services (Baker and Hamilton, 2006). Job creation improves outside options and local services compete with the provision of the same services by Muqtada al Sadr and other religious rebels.

The model offers essentially constructive policies to limit militia activity. It suggests at the very least a two-pronged strategy for countering terrorists and militias. One prong would be conventional: intelligence, infiltration, deterrence and counterattack, including weakening the benign infrastructure of organizations like Hamas and The Taliban, that provide both benign and violent local public goods. The other would be constructive: economic development and aid to stabilize governments which provide local public goods in a manner that does not discriminate between club members and nonmembers.

We must reiterate that the two constructive policy recommendations, improving public good provision and outside (market) options may sound like conventional development economics, ${ }^{44}$ but they are not. First, since the aim is not to maximize social welfare or economic growth, but rather to undermine terrorism and insurgency, public goods and outside options are aimed at the small proportion of the population for whom defection and leaks of information are relevant. While it may seem counterintuitive, this approach implies improving services and providing outside options to the very groups that profiling predicts are most likely to yield recruits to insurgency and terrorism. Second, providers of public services will likely be targeted by terrorist clubs and must be protected, including members of NGOs. Third, public service provision should attempt to directly compete with services provided by clubs, rather than concentrate on services not otherwise provided. That provision must never be captured by clubs, in the sense that access to those services is denied to nonmembers, as sometimes happens to NGO programs. ${ }^{45}$

The general conclusion from this discussion for counter-terrorism is that the threat of defection is a powerful force limiting the tactical choices of terrorists. As we mentioned in the Introduction, the assassination of Abu Musab Al-Zarqawi in Iraq was made possible by leaked information. Since 1996 Jamal Ahmed al-Fadl of Sudanese Al-Qaeda has been sharing information in return for

\footnotetext{
44 There are also policy implications for political development. Recall that project size for militia is limited by the incentive compatibility constraint (5). If political representation analyzed as a government-provided local public good, $G$, then an increase in representation will limit project size (as illustrated in Fig. 5 of Berman and Laitin (2008)). Political representation is special in this context because it allows a sect to organize politically (or militarily) and influence - or even become, the government. Their incentives to do so are amplified if government can discriminate in favor of club members, as the Taliban government did. A constitutional promise not to discriminate along religious or ethnic lines, such as church state separation, dampens incentives of sects to organize politically or as militias (Iannaccone and Berman, 2006).

${ }^{45}$ Shawn Flanigan (2008) describes how World Bank funds to build housing in war-affected parts of Sri Lanka were diverted to build a "Heroes' Village," reserved for the families of LTTE fighters who had died in battle.
} 
protection and rewards. His defection has led to four convictions so far. While radical religious clubs have an advantage, they are still vulnerable to defection. Considering the loyalty required of operatives in the face of tempting incentives, we should explore how bonds of loyalty can be frayed. In this sense effectively defending high-value targets against suicide attacks requires recognizing the interaction of target hardness and the defection constraints faced by radical religious clubs, the groups which are most effective in hard-target environments.

\section{Conclusions}

Can rational choice modeling explain the lethality of radical religious militias and why they choose suicide attacks? Our investigation was motivated by several empirical patterns: Though insurgencies typically target poor, hilly countries, suicide attacks are as likely to target rich, flat countries. Though insurgents often kill coreligionists, they seldom use suicide attacks to do so. Though many types of groups rebel, radical religious rebels use suicide attacks more often.

To explain these patterns, we analyzed radical religious rebel groups. We first asked what a rational suicide terrorist would have to believe and discussed the role of religion in those beliefs. Standard rational choice accounts find that with plausible utility functions, recruitment of martyrs does not require appeals to irrationality or utter fanaticism. The real test of the rational model is not to explain recruitment of attackers, but rather the management of operatives who will resist the temptation to defect when organizing high-stakes attacks. To address this strategic problem, we proposed a club good model that emphasizes the function of voluntary religious organizations as efficient providers of local public goods. The sacrifices that these groups demand enable benign mutual aid but are also well suited for solving the extreme principal-agent problems in recruiting and managing operatives who will not defect. Thus, religious radicals are effective (though not unique) dispatchers of suicide bombers. The model also analyzed the choice of suicide attacks as a tactic, predicting that suicide will be used when targets are well protected and when damage is potentially great. Those predictions are consistent with the patterns described in the last paragraph. Our model had testable implications for tactic choice and for damage achieved by terrorists. These are supported by data on lethality and target choice from the Israel/Palestine conflict and broadly consistent with observations from Iraq, Chechnya and Sri Lanka.

We have argued for a functional, economic view of radical religious militias. This is a unifying approach, derived from a model that rationalizes the behavior of Christian religious sects (Iannaccone, 1992) and ultra-orthodox Jews (Berman, 2000). Without minimizing the motivating force of theology, ideology and grievances for rebels, we emphasize that they are poor predictors of civil war (FL). Even where angry zealots are common it seems to be those who can organize clubs that threaten governments. ${ }^{46}$ These $^{2}$ topics, which economists have generally left to the tools of sociologists and anthropologists, might benefit from reexamination using the club model.

A rational choice explanation is hopeful news for policy interventions based on constructive incentives. Those policy implications for combating terrorism flow from an understanding that three institutions compete to provide economic services to members of religious sects: market, government and sect. When sects prevail they can use their influence and information to run militias with deadly efficiency. They form efficient militias because providing social services cooperatively and cooperative militia operations are very similar activities. If markets and governments prevail, sects are weakened because defection to the secular alternative becomes more attractive. Sect militias become harder to organize and easier to infiltrate.

The models' recommendations are essentially constructive. A government wanting to weaken a religious militia such as the Taliban, Hamas or Sadr's militia in Iraq, should strive to create outside options for rebels and replace the social services provided by the militia's parent religious sect with services provided by some combination of functioning markets, government, and nondiscriminatory NGOs. One approach could be to weaken the benign infrastructure of a particular radical sect, but in order to inoculate a society against religious militias in general and in the long run, the analysis recommends developing the necessary institutions of a well-functioning market economy, with all the complexity and effort involved. This approach is distinct from conventional economic and political development in its emphasis on profiling and (benignly) targeting individuals and communities with potential for rebellion and terrorism.

An apparent problem for our model concerns income and tactic choice. In the model poverty should breed terrorism as it lowers the outside options of club members. Yet Berrebi (2003) and Krueger and Maleckova (2003) find that leaders and suicide attackers tend to have about the same income levels as their neighbors, and higher educational levels. This may be due to selection, as pointed out by Becker and Posner (2005). The harder the targets, the more leaders will select the most educated cadre available who can be trusted, as shown by Benmelech and Berrebi (2007) using evidence from Israel/Palestine. One wouldn't think that bin Laden's lieutenants would choose illiterate Afghan Jihadists for flight school in Florida if disaffected students in Europe were available. Those attackers can be relatively well-to-do but they would be reliable to the extent that they have credibly foresworn outside options. To illustrate the power of selection, imagine a population with a distribution of individual beliefs, a small minority of which are extreme or even pathological (a Timothy McVeigh, for example). In isolation from an organized militia, these individuals seldom do much harm, and when they do these acts are isolated and nonrecurring. Now imagine a provider of benign social services whose contact with that population allows it to observe signals of belief. That provider could then identify extremists and recruit a militia, harvesting the extreme tail of the distribution of beliefs. Once identified, organized and armed, that small minority could cause recurring damage.

\footnotetext{
${ }^{46}$ One special aspect of religious organizations in this context is that since they make supernatural promises, the ultimate credence goods, they have a special interest in creating credibility among their leadership and membership (Iannaccone and Berman, 2006). That credibility may ease defection constraints.
} 
More theoretical and empirical work is needed to account formally for nonreligious clubs and the reliance on cadres with high outside options. The club model shares some testable implications with the "rational peasant" model of information leaks in counterinsurgency (Popkin, 1970), which has distinct policy implications. Even with data on the dependent variables presented here, there are further tests. For example, our model implies that the more benign local public goods (mutual insurance, physical protection) provided by clubs to members, the lower the defection rate. That would be especially true when the state and market do not provide substitutes to these services, as in failed states. Another implication is that the greater an attack's potential damage, the stronger the incentive to defect. These require testing. We leave to future research the questions of why clubs choose violence over nonviolent mobilization, and what their objectives are in doing so.

In environments of asymmetric warfare the hardness of targets gives a comparative advantage to clubs among insurgents. So we forecast more radical religious rebels, not because of a religious resurgence but because as governments grow stronger warfare becomes increasingly asymmetric. The U.S., other high-income countries, and allies they come to the aid of present hard-target environments to insurgents. So radical religious clubs using suicide attacks are opponents these countries should expect to face. The policy implications are straightforward. Further hardening of targets may reduce overall violence but will increase suicide attacks and may lead to proliferation of radical clubs. Policies that encourage defection by improving options outside the club and by competing with club-provided services shrink the incentive-compatible set of targets for terrorists in general and for suicide attackers in particular.

\section{References}

Armstrong, Karen, 2000. The Battle for God. Ballantine, New York.

Asal, Victor, Rethmeyer, Karl, R., 2008. The nature of the beast: organizational structures and the lethality of terrorist attacks. The Journal of Politics 70 (2), 1-13. Baker, James A. III, Hamilton, Lee H., 2006. The Iraq Study Group Report. Nov., usip.org.

Becker, Gary S., 1968. Crime and punishment: an economic approach. Journal of Political Economy 76 (2), 169-217. March.

Becker, Gary S., Posner, Richard A., 2005. Suicide and risk taking: an economic approach. U. of Chicago mimeo.

Ben-Porath, Yoram, 1980. The F-connection: families, friends and firms and the organization of exchange. Population and Development Review 6, 1-29.

Benmelech, Efrain, Berrebi, Claude, 2007. Human capital and the productivity of suicide bombers. Journal of Economic Perspectives 21 (3), $223-238$.

Berman, Eli, 2000. Sect, subsidy and sacrifice: an economist's view of Ultra-Orthodox Jews. Quarterly Journal of Economics 115 (3).

Berman, Eli, 2003. Hamas, Taliban and the Jewish underground: an economist's view of radical religious militias. NBER WP 10004. October.

Berman, Eli, in press. Sects and Violence for Economists: Religion, Community and Terrorism, MIT Press.

Berman, Eli, Laitin, David D., 2007. Symposium on suicide terrorism. Perspectives on Politics 5 (1), 122-129.

Berman, Eli, Laitin, David D., 2008. Religion, terrorism and public goods: testing the club model. National Bureau of Economic Research WP \#13725. January.

Berman, Eli, Stepanyan, Ara, 2005. How many radical Islamists? Indirect evidence from five countries. UCSD mimeo. October.

Berrebi, Claude, 2007. Evidence About the Link Between Education, Poverty and Terrorism among Palestinians. . Peace Economics, Peace Science and Public Policy, vol. 13 (1). Berkeley Electronic Press.

Black, Anthony, 2001. The History of Islamic Political Thought. Routledge, New York.

Bloom, Mia, 2005. Dying to Kill. Columbia University Press, New York.

Camerer, Colin, 1988. Gifts as economic signals and social symbols. American Journal of Sociology 96, S180-S214.

Chen, Daniel, 2005. Club Goods and Group Identity: Evidence from Islamic Resurgence During the Indonesian Financial Crisis. University of Chicago mimeo.

Collier, Paul, Hoeffler, Anke, 2001. Greed and Grievance in Civil War. http://econ.worldbank.org/programs/library.

Davis, Anthony, 1999. How the Taliban became a military force. In: Maley, William (Ed.), Fundamentalism Reborn? Afghanistan and the Taliban. New York University Press, New York.

Dodge, Toby, 2004. "Political mobilisation in the absence of civil society or a state; Islamic nationalism in post-Saddam Iraq. University of London mimeo.

Elster, Jon, 2006. Motivations and beliefs in suicide missions. In: Gambetta, D. (Ed.), Making Sense of Suicide Missions. Oxford University Press, Oxford.

Esposito, John, 2002. What Everyone Needs to Know about Islam. Oxford University Press, New York.

Fandy, Mamoun, 1999. Saudi Arabia and the Politics of Dissent. St. Martin's Press, New York.

Fearon, James D., Laitin, David D., 2003. Ethnicity, insurgency and civil war. American Political Science Review 97 (1), $75-90$.

Flanigan, Shawn Teresa, 2008. Nonprofit service provision by insurgent organizations - the cases of Hizballah and the Tamil Tigers. Studies in Conflict and Terrorism 31 (6). Gambetta, Diego, 2006. Making Sense of Suicide Missions. Oxford University Press, Oxford. (softcover, revised and updated edition).

Hamermesh, D., Soss, N., 1974. An economic theory of suicide. Journal of Political Economy 82 (1), 83-98.

Hassan, Nasra, 2001. An arsenal of believers: talking to the 'human bombs. New Yorker, November 19.

Hoffman, Bruce, 2001. All you need is love: how the terrorists stopped terrorism. Atlantic Monthly. December.

Hopgood, Stephen, 2006. Tamil Tigers, 1987-2002. Gambetta, pp. 43-76.

Iannaccone, Laurence R., 1992. Sacrifice and stigma: reducing free-riding in cults, communes, and other collectives. Journal of Political Economy $100,271-291$.

Iannaccone, Laurence R., Berman, Eli, 2006. Religious Extremism; the good, the bad and the deadly. Public Choice 128 (1-2), 109-129.

Jervis, Robert, 1976. Perception and Misperception in International Politics. Princeton U. Press, Princeton.

Juergensmeyer, Mark, 2000. Terror in the Mind of God: The Global Rise in Religious Violence. University of California Press, Berkeley.

Krueger, Alan B., Maleckova, Jitka, 2003. Education, poverty, political violence and terrorism: is there a causal connection? Journal of Economic Perspectives 17, 119-144.

Kruglanski, Arie, 2002. Inside the terrorist mind. National Academy of Sciences presentation, April.

Merari, Ariel, 2004. Suicide terrorism in the context of the Israeli-Palestinian conflict. National Institute of Justice Suicide Terrorism Conference, October 25-26, Washington, DC

Mishal, Shaul, Sela, Avraham, 2000. The Palestinian Hamas: Vision, Violence and Coexistence. Columbia University Press, New York.

Mitchell, Richard P., 1969. The Society of Muslim Brothers. Oxford University Press, London.

Munson, Ziad, 2002. Social movement theory and the Egyptian Muslim brotherhood. Sociological Quarterly 42.

Pape, Robert A., 2003. The strategic logic of suicide terrorism. American Political Science Review 97.

Pape, Robert A., 2005. Dying to Win. Random House, New York.

Popkin, Samuel L., 1970. Pacification: politics and the village. Vietnam: Politics, Land Reform and Development in the Countryside. Asian Survey, vol. 10(8), pp. 662-671. August.

Rashid, Ahmed, 2000. Taliban: Militant Islam, Oil and Fundamentalism in Central Asia. Yale, New Haven.

Rashid, Ahmed, 2002. Jihad: The Rise of Militant Islam in Central Asia. Yale University Press, New Haven.

Rosenthal, Howard, 2003. Suicide bombing: what is the answer? Princeton, mimeo.

Schiff, Zeev, Ya'ari, Ehud, 1990. The Palestinian Uprising-Israel's Third Front. Simon \& Schuster, New York.

Shapira, Shimon, 2000. Hizbullah between Iran and Lebanon. Hakibbutz Hameuchad, Tel Aviv. 
Shapiro, Jacob N., Siegel, David A., 2007. Underfunding in terrorist organizations. International Studies Quarterly 51 (2), 405-429.

Smith, Adam, 1965. An Inquiry into the Nature and Causes of the Wealth of Nations. Modern Library, New York. (Reprint of 1776 version). Spence, A. Michael, 1973. Job market signaling. Quarterly Journal of Economics 87 (3), 355-374.

Sprinzak, Ehud, 2000. Rational fanatics. Foreign Policy 120, 66-73.

Stark, Rodney, Finke, Roger, 2000. Acts of Faith: Explaining the Human Side of Religion. University of California Press, Berkeley. Swamy, M.R. Narayan, 1994. Tigers of Lanka: From Boys to Guerrillas. Konark Publishers, Delhi.

Thompson, Robert, 1966. Defeating Communist Insurgency: The Lessons of Malaya and Vietnam. Praeger, New York.

Tishkov, Valery, 2004. Chechnya: Life in a War-Torn Society. University of California Press, Berkeley.

Trajtenberg, Manuel, 2006. Defense R \& D in the anti-terrorist era. Defence and Peace Economics 17.

Weber, Max, 1978. Economy and Society. University of California Press, Berkeley, California

Wintrobe, Ronald, 2006. Rational Extremism. Cambridge University Press, Cambridge. 